\title{
48. MINERAL ASSEMBLAGES AND PROCESSES OF ALTERATION IN BASALTS AT DEEP SEA DRILLING PROJECT SITES 417 AND 418
}

\author{
N.N. Pertsev and V.L. Rusinov, Institute of Geology of Ore Deposits, Petrography, Mineralogy and Geochemistry, \\ USSR Academy of Sciences, Moscow
}

\section{INTRODUCTION}

The low-temperature alteration of basalts drilled on Legs 51 through 53 is manifested widely, although its intensity varies in different drill holes and at different depths. The most intensely altered are the basalts from Hole $417 \mathrm{~A}$ and the fine-grained basalt differentiates, irrespective of depth. The mineralogy of the alteration products is generally similar to that of the altered basalts from the drill holes of Leg 37 (Robinson et al., 1977) and from dredge samples of oceanic basalts taken at the Mid-Atlantic Ridge (Scott and Hayash, 1976; Hart, 1973). The aim of this paper is to discuss the mineralogy of the basalts from Legs 51 through 53 , the distribution of alteration products at various depth intervals, and the mineral assemblages and conditions of formation.

\section{MINERALS OF ALTERATION PRODUCTS}

Among the basalt alteration products, we have identified clay minerals of a montmorillonite group (smectites), hydromicas (celadonite), mixed-layer minerals (montmorillonite-celadonite), $\mathrm{K}$-feldspar, minerals of the zeolite group (natrolite, phillipsite), analcime, apophyllite, calcite, manganocalcite, dolomite, magnesite, quartz and chalcedony, opal, pyrite and chalcopyrite, and iron hydroxides.

The most widespread alteration products of the basalts under investigation are the smectite-group clay minerals. Smectites are developed as pseudomorphs after olivine in phenocrysts and groundmass, in the alteration products of the groundmass glass, in vesicle and veinlet fillings, and in the altered groundmass and veinlets in plagioclase phenocrysts.

Smectites vary greatly in color: from colorless to dirty yellow, olive-green and olive-brown, bright brown and bright reddish brown. Most abundant are smectites with a light olive-green or olive-brown color (in thin section). Different colors are produced by variations in composition. On the basis of optical properties and chemical composition, the smectites can be classified into three groups:

1) Brown magnesium ferrismectites;

2) Green and light-brown magnesium aluminosmectites; and

3) Colorless or light colored calcium aluminosmectites.

The chemical compositions of smectites are given in Figures 1 and 2. Common to all the groups is the generally low potassium content (from 0.01 atoms per unit cell). Some samples have a considerably higher potassium content, but this is attributed to mixed layering (that is, the presence of mica packets). In the space between the layers either calcium (group 3) or magnesium (groups 1 and 2) occurs. A characteristic of the smectites is their marked variation in

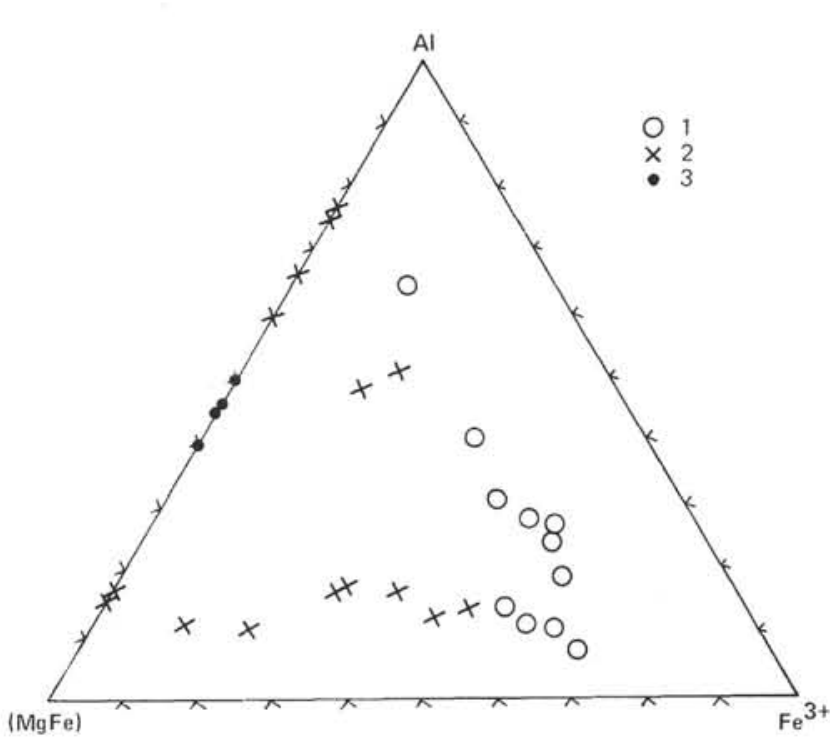

Figure 1. Composition of celadonites (1), smectites (2), and palagonites (3) in basalts and breccia. Holes 417A, $417 D$, and $418 \mathrm{~A}$.

degree of iron oxidation. In some samples iron replaces aluminum not only in octahedrons but also in tetrahedrons. A further remarkable feature of smectites is their extremely low sodium content or even its complete absence. Details of the chemical composition and structure of smectites are given in a separate chapter.

It is noteworthy that the smectites of group 3 are developed after plagioclase phenocrysts, while those of groups 1 and 2 fill in vesicles, pseudomorphs after olivine, and cracks, frequently alternating with each other or with celadonite. Also, the smectites of group 1 appear to have formed at the expense of glass decomposition. Smectites of different colors can be found in one and the same thin section, often forming radular color transitions. Frequently, they create distinct zoning in vesicle and vein fillings. Such zoning is emphasized not only by color differences but also by the contamination of some zones by dispersed iron and manganese oxides (Plate 1, Figure 1). The smectite developed after olivine phenocrysts in pseudomorphs is normally large foliated with notable pleochroism, darker olive-brown along $\gamma$ and $\beta$, and lighter along $\alpha$. In vesicle fillings, only thin rims at the edges appear to be large foliated (radiate-fibrous) (Plate 1, Figure 2). In vesicle cores and veinlets, the smectite is usually cryptogranular.

Celadonite is less widespread than smectite. It is abundant at the top of the basalt section, particularly in Hole 


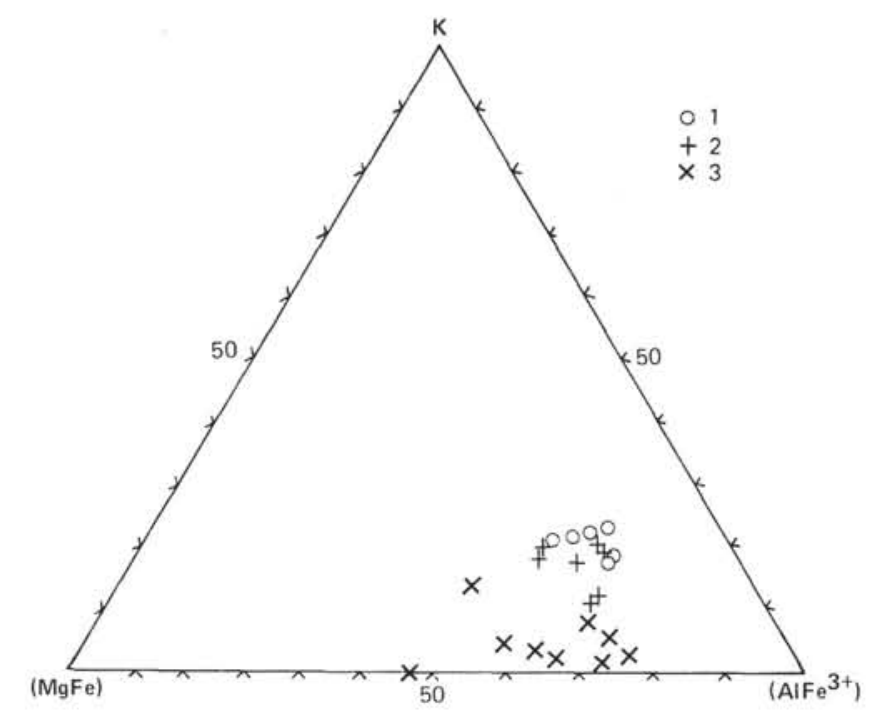

Figure 2. Composition of celadonites $(1=$ of Legs 51 through 53), (2 = of Legs 51 through 53 after Deer et al., 1964) and smectites (3 of Legs 51 through 53).

417A. In origin and form, it is similar to smectites but differs from them in color. Celadonite is commonly bright green. It manifests strong pleochroism in large-foliated accumulations (in pseudomorphs after olivine and in rims of vesicle fillings). As to composition, celadonite differs from smectites on account of its higher $\mathrm{K}_{2} \mathrm{O}$ content.

The chemical composition of celadonites is given in Figures 1 and 2. A high degree of aluminum replacement by iron oxides in both octahedrons and tetrahedrons is evident. It is remarkable that, in addition to $\mathrm{K}_{2} \mathrm{O}, \mathrm{CaO}$ is always present, although in small amounts, in a group of interlayered cations, whereas $\mathrm{Na}_{2} \mathrm{O}$ is frequently absent. Celadonite has a very high degree of iron oxidation. This is always found in patches of intense basalt oxidation. The composition of this mineral has been described in detail (Rusinov, Gradusov, et al., this volume).

In addition to the common bright green celadonites, brown varieties have been found. At first, these were described as brown smectites, but subsequently, having been analyzed with a microprobe, they were attributed to micas. Brown celadonites were observed as products of glass replacement at the rims of vesicles, and as worm-shaped broken bands of decomposed glass inside vesicles filled with calcite. Brown celadonites have the same composition as green celadonites; their brown color is caused by absorbed iron oxides separated as a result of glass decomposition.

Celadonite often occurs together with smectite, occasionally forming gradual color transitions (mixed-layer varieties?), but more often with a distinct boundary between them.

Carbonates are almost always present in the basalt alteration products, although they are less abundant and widespread than smectites. In addition to calcite, manganous calcite, dolomite, and magnesite are found.

Calcite forms are similar to those of clay minerals. Calcite occurs as pseudomorphs after olivine, products of glass substitution in the groundmass, and vesicle and vein fillings. In aggregate structure, calcites occur as fine-grained types with dispersed clay particles; radiate-fibrous in vesicle, veinlet, and cavity fillings; cross-fibrous and crossprismatic in minute veinlets $(1 \mathrm{~mm})$ in basalt or in olivine phenocrysts; and finally, as block calcite, pure or contaminated with dispersed clay minerals. Block calcite is widespread in pseudomorphs, vesicles, and veins. Radiatefibrous aggregates are often cemented with block calcite. Also, calcite occurs in crystals incrustating small cavities, and in crystals found in the quartz or smectite matrix.

Dolomite was found only in Hole 418A (Specimen 51-5, $68 \mathrm{~cm}$ and Sample $63-2,18-25 \mathrm{~cm}$ ). In the first instance, it occurs with ferruginous magnesite in a thin vein at the chilled brecciated edge of a pillow lava. The optical measurements yielded $\gamma=1.675 \pm 0.003$. On the basis of refractive index, $\alpha=1.553 \pm 0.003$, the magnesite in the vein consists of 37 per cent siderite and 63 per cent magnesite. In the second instance, dolomite, together with quartz, is developed in crystals incrustating the walls of a large cavity in basalt (Figure 3 ).

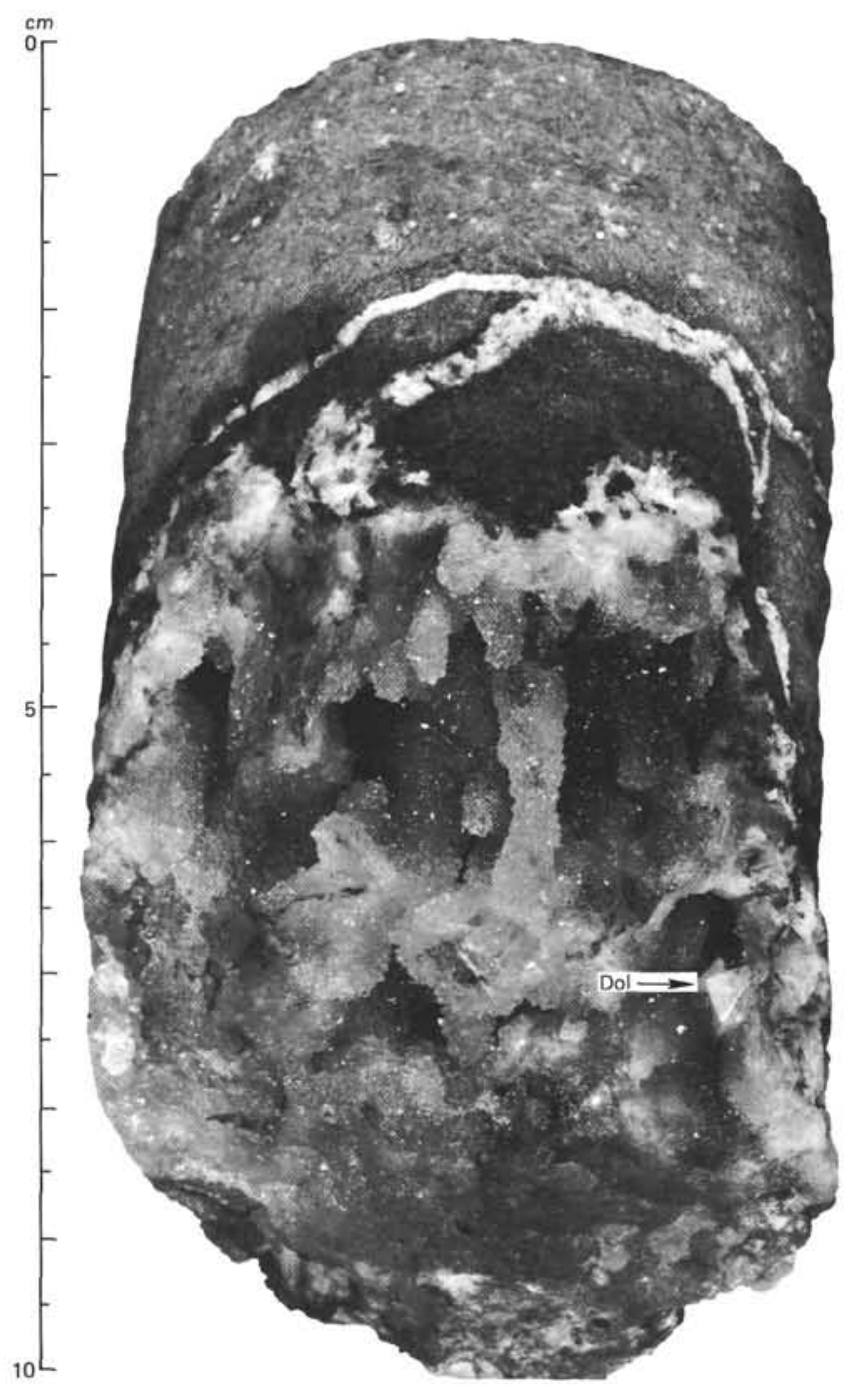

Figure 3. A cavity in basalt with small crystals of quartz and dolomite (Dol) covering the cavity walls; 418A-63-2, $18-25 \mathrm{~cm}$. 
Manganous calcite in Sample 417A-24-2, 81-84 cm fills the interior of an irregular vesicle together with pale green, fine-flake montmorillonite. Inside the calcite, idiomorphic zeolite crystals occur displaying rectangular patterns in thin sections. The crystal bases are located at the contacts between calcite and montmorillonite. In addition to calcium and manganese, calcite contains very little magnesium. The montmorillonite associated with the calcite is attributed to a group of calcium aluminomontmorillonites. It is rich in manganese oxide ( 0.08 per cent). Small amounts of $\mathrm{MnO}$ (less than 1 per cent) are often found in the calcite samples.

Silica minerals are limited in distribution. They are represented by quartz and, more rarely, by chalcedony and opal. Quartz occurs in radiated spherical accumulations in the cores of large calcite veins or in cavities (Plate 1, Figure 3 ), in incrustations lining the walls of cavities (Figure 3), in irregular granular (or chalcedonic) masses filling vesicles along with calcite and smectite (Plate 1, Figure 4), or in pseudomorphs after olivine phenocrysts (Plate 2, Figure 1).

Opal is relatively scarce. It fills minute veinlets in smectites at brecciated glassy edges, or forms rims around smectite or calcite fillings of vesicles (Plate 2, Figure 2).

$\mathrm{K}$-feldspar is fairly widespread in the alteration products of basalts from Holes $417 \mathrm{~A}$ and $418 \mathrm{~B}$, and at the top of the basalt series in deep drill holes. In Hole 418A, most of the $\mathrm{K}$-feldspar accumulations are found above the breccia zone (Cores 31 through 42) rather than at the top of the drill hole.

$\mathrm{K}$-feldspar occurs as pseudomorphs after plagioclase. In the case of unintensive K-feldspar formation, only the most basic plagioclases developed in phenocryst cores are substituted. More acid plagioclase occurring in rims and microlites remains unsubstituted (Plate 2, Figure 3).

As alteration proceeds, plagioclase is being replaced. In addition to K-feldspar, plagioclase is replaced by light colored smectite, fine-grained calcite, and, in some samples, phillipsite. K-feldspar is formed near veins and fissures in near-fracture zones of basalt oxidation. This fact was overlooked at the preliminary examination of cores onboard ship.

The K-feldspar was identified using optical and X-ray analysis; its chemical composition was determined by a microprobe (Table 1). From the value $-2 \mathrm{~V}=60^{\circ}$ to $70^{\circ}$, it corresponds to microcline with a 0.5 degree of ordering; $\gamma$ $=1.523, \alpha=1.517 \pm 0.002$.

TABLE 1

Microprobe Analyses of Zeolites and Other Newly Formed Minerals

\begin{tabular}{|c|c|c|c|c|c|c|c|c|c|c|}
\hline Oxides & 1 & 2 & 3 & 4 & 5 & 6 & 7 & 8 & 9 & 10 \\
\hline $\mathrm{SiO}_{2}$ & 65.4 & 64.0 & 61.3 & 49.4 & 53.9 & 51.6 & 49.4 & 63.4 & - & - \\
\hline $\mathrm{TiO}_{2}$ & 0.0 & 0.0 & 0.0 & 0.0 & 0.0 & 0.0 & 0.0 & 0.0 & - & - \\
\hline $\mathrm{Al}_{2} \mathrm{O}_{3}$ & 19.3 & 17.8 & 20.1 & 32.9 & 17.1 & 0.09 & 0.0 & 19.2 & - & - \\
\hline $\mathrm{FeO}$ & 0.44 & 0.22 & 0.13 & 0.5 & 0.0 & 0.0 & 0.0 & 0.0 & 0.59 & 0.0 \\
\hline $\mathrm{MnO}$ & 0.0 & 0.0 & 0.0 & 0.0 & 0.0 & 0.0 & 0.0 & 0.0 & 0.17 & 10.3 \\
\hline $\mathrm{MgO}$ & 0.0 & 0.0 & 0.0 & 0.22 & 0.0 & 0.0 & 0.0 & 0.0 & 0.76 & 0.64 \\
\hline $\mathrm{CaO}$ & 0.28 & 0.30 & 0.50 & 16.3 & 0.9 & 23.8 & 23.9 & 0.0 & 55.7 & 43.6 \\
\hline $\mathrm{Na}_{2} \mathrm{O}$ & 3.8 & 4.1 & 1.4 & 2.5 & 9.7 & 0.13 & 0.04 & 0.0 & - & - \\
\hline $\mathrm{K}_{2} \mathrm{O}$ & 4.5 & 5.3 & 4.2 & 0.0 & 3.0 & 4.6 & 4.66 & 16.1 & - & - \\
\hline Total & 93.72 & 91.72 & 87.93 & 101.8 & 84.6 & 80.26 & 78.04 & 98.7 & 57.2 & 54.54 \\
\hline
\end{tabular}

Note: $1-4=$ Zeolites $(1-3=$ Sample $417 \mathrm{D}-30-5,67-73 \mathrm{~cm} ; 4=$ Sample $417 \mathrm{~A}-24-1,86-90 \mathrm{~cm})$

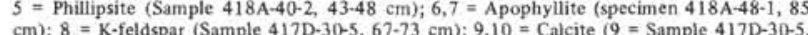
$\mathrm{cm}) ; 8=\mathrm{K}$-feldspar $($ Sample $417 \mathrm{D}-30-5,67-73 \mathrm{~cm}) ; 9,10=$ Calcite $(9=$ Sample 417D-30-5 $67-73 \mathrm{~cm} ; 10=$ Sample $417 \mathrm{~A}-24-1,86-90 \mathrm{~cm}$ ). Analysts: L.P. Laputina and G.N. Muravitskaja. The sample of apophyllite was analyzed also by wet chemistry (analyst: E.P. Frolova) $0.07 ; \mathrm{K}_{2} \mathrm{O}-5.00 ; \mathrm{H}_{2} \mathrm{O}^{-}-0.45 ; \mathrm{H}_{2} \mathrm{O}^{+}-13.16 ; \mathrm{F}^{-2}-01 ; \mathrm{Total}=\left(100.64-0.84 \mathrm{~F}_{2}=\mathrm{O}\right)=99.80 \mathrm{wt}$. \%.
Apophyllite was found only in Hole 418A (Specimens $42-4,142 \mathrm{~cm}$ and $48-1,86 \mathrm{~cm}$ ); originally, onboard ship, it was identified as thomsonite. The mineral occurs in tabular aggregates up to $8 \mathrm{~mm}$ in cross section displaying perfect cleavage. It is found in intensely altered patches of basalt in unconsolidated smectite masses (Plate 2, Figure 4). The apophyllite crystals are extremely pure; $\gamma=1.533 \pm 0.002$, $\gamma-\alpha=0.001$. The chemical analysis and X-ray pattern data are given in Tables 1 and 2, respectively.

Analcime was found in druses in relatively large cavities in altered basalts (Figure 4). In minute veinlets and pseudomorphs after olivine phenocrysts, some analcime crystals reach $1 \mathrm{~cm}$ in size. The mineral was identified on the basis of X-ray diffraction analysis. (Table 2). Analcime is found in the samples from Hole 417A below a depth of 280 meters ( $60 \mathrm{~m}$ below basalt basement) and from Hole $418 \mathrm{~A}$ in an interval of $475-485$ meters (about $160 \mathrm{~m}$ below basalt basement). It is present both in basalts and in breccias. Remarkably, analcime was found only in moderately altered rocks and never in poorly altered and in highly altered basalts containing a great amount of secondary K-feldspar.

The analcime content is commonly low (1 to 3 per cent), which is attributed to its formation in moderately altered

TABLE 2

X-Ray Powder Data for Newly Formed Minerals in Basalts From Holes 417A and 418A

\begin{tabular}{|c|c|c|c|c|c|c|c|c|c|c|c|}
\hline \multicolumn{2}{|c|}{1} & \multicolumn{2}{|l|}{2} & \multicolumn{2}{|l|}{3} & \multicolumn{2}{|l|}{4} & \multicolumn{2}{|l|}{5} & \multicolumn{2}{|c|}{6} \\
\hline $\mathrm{d} / \mathrm{n}$ & I & $\mathrm{d} / \mathrm{n}$ & I & $\mathrm{d} / \mathrm{n}$ & I & $d / n$ & 1 & $\mathrm{~d} / \mathrm{n}$ & I & $d / n$ & 1 \\
\hline - & - & - & - & - & - & 14.04 & 1 & - & - & - & - \\
\hline - & - & - & - & - & - & 8.47 & 2 & 9.3 & 4 & - & - \\
\hline- & - & - & - & 7.69 & 4 & 7.69 & 8 & - & - & - & - \\
\hline 6.52 & 8 & 6.15 & 7 & 7.05 & 9 & - & - & 7.14 & 3 & - & - \\
\hline 5.96 & 7 & 5.58 & 10 & 5.32 & 6 & 6.25 & 1 & - & - & - & - \\
\hline 4.64 & 6 & 4.82 & 7 & 4.98 & 7 & 4.94 & 7 & - & - & - & $\overline{7}$ \\
\hline 4.44 & 7 & - & - & 4.56 & 1 & 4.46 & 7 & - & - & 4.23 & 7 \\
\hline 4.15 & 6 & - & - & 4.10 & 8 & - & - & $4.12^{\mathrm{X}}$ & 3 & 3.95 & 1 \\
\hline 3.83 & 1 & 3.77 & 7 & 3.94 & 1 & 3.88 & 9 & 3.74 & 2 & 3.83 & 5 \\
\hline 3.50 & 2 & 3.67 & 1 & 3.67 & 1 & - & - & - & - & 3.65 & 2 \\
\hline- & - & 3.40 & 10 & 3.51 & 7 & 3.53 & 7 & $3.31^{x}$ & 2 & 3.46 & 1 \\
\hline- & - & 3.23 & 4 & 3.27 & 8 & 3.27 & 1 & 3.22 & 2 & 3.33 & 10 \\
\hline 3.18 & $10 \mathrm{~d}$ & - & - & 3.15 & 10 & 3.14 & 1 & 3.08 & 4 & 3.26 & 8 \\
\hline 2.93 & 3 & 2.92 & 10 & 2.97 & 7 & 2.94 & 10 & $2.97^{x}$ & 10 & 3.02 & 6 \\
\hline 2.85 & 10 & - & - & - & - & - & - & - & - & 2.94 & 6 \\
\hline 2.72 & 1 & 2.77 & 2 & 2.74 & 7 & 2.74 & 2 & 2.71 & 3 & 2.78 & 3 \\
\hline 2.60 & 2 & 2.69 & 6 & 2.68 & 8 & 2.66 & 1 & - & - & 2.60 & 7 \\
\hline 2.43 & 4 & 2.50 & 6 & 2.56 & 1 & 2.47 & 10 & $2.49^{\mathrm{x}}$ & 4 & 2.42 & 2 \\
\hline 2.37 & 1 & 2.41 & 3 & 2.35 & 1 & 2.41 & 1 & - & - & - & - \\
\hline 2.26 & 1 & 2.22 & 5 & 2.22 & i & 2.19 & i & $2.27^{x}$ & 4 & 2.20 & 4 \\
\hline 2.20 & $4 b$ & 2.19 & 1 & 2.16 & 1 & 2.15 & 1 & - & - & 2.16 & 2 \\
\hline 2.07 & 1 & 2.09 & 2 & 2.05 & i & 2.10 & 8 & $2.08^{x}$ & 4 & 2.08 & 0.5 \\
\hline 2.00 & 1 & 2.02 & 1 & 1.961 & 2 & 1.993 & 4 & - & - & 1.995 & 2 \\
\hline 1.889 & 2 & 1.901 & 7 & 1.906 & i & 1.941 & 2 & $1.897^{x}$ & SB & 1.949 & 1 \\
\hline 1.836 & 2 & 1.863 & 6 & - & - & - & - & - & - & 1.862 & 2 \\
\hline 1.815 & 5 & - & - & 1.824 & 1 & - & - & - & - & 1.813 & 8 \\
\hline 1.739 & 3 & 1.742 & 7 & 1.771 & 6 & 1.766 & 8 & 1.783 & 2 & - & - \\
\hline 1.717 & 1 & 1.716 & 2 & 1.721 & 5 & - & - & - & - & - & - \\
\hline- & - & 1.690 & 3 & 1.672 & 4 & - & - & 1.676 & 1 & 1.689 & 1 \\
\hline- & - & 1.664 & 1 & - & - & - & - & - & - & 1.650 & i \\
\hline 1.638 & 2 & 1.636 & 1 & 1.627 & 3 & - & - & - & - & - & - \\
\hline 1.617 & $3 \mathrm{~d}$ & 1.595 & 4 & 1.593 & 2 & - & - & $1.606^{x}$ & 2 & 1.606 & 0.5 \\
\hline 1.589 & 3 & 1.561 & 1 & - & - & 1.573 & 7 & - & - & 1.572 & 1 \\
\hline 1.541 & 2 & - & - & 1.538 & 2 & 1.541 & 6 & $1.526^{\mathrm{x}}$ & 1 & 1.539 & 2 \\
\hline 1.528 & 1 & 1.498 & 3 & 1.508 & 1 & 1.492 & 4 & - & - & 1.515 & 8 \\
\hline 1.473 & 5 & 1.481 & 3 & 1.479 & 6 & - & - & $1.485^{x}$ & 1 & - & - \\
\hline 1.452 & 1 & 1.448 & 2 & 1.421 & 1 & 1.458 & 2 & 1.462 & 1 & 1.450 & 4 \\
\hline 1.424 & 2 & 1.415 & 6 & 1.391 & 2 & - & - & $1.442^{x}$ & 2 & 1.416 & 3 \\
\hline 1.398 & 3 & - & - & - & - & - & - & - & - & 1.396 & 2 \\
\hline 1.375 & 1 & 1.373 & 1 & 1.365 & 6 & - & - & - & - & - & $=$ \\
\hline 1.352 & 2 & 1.351 & 1 & - & - & - & - & - & - & 1.352 & 1 \\
\hline 1.333 & 2 & - & - & - & - & - & - & - & - & 1.319 & 4 \\
\hline 1.311 & 5 & 1.308 & 3 & 1.322 & 4 & - & - & - & - & 1.304 & 4 \\
\hline
\end{tabular}

Note: 1 = Natrolite $($ Specimen 417A-38-8, $82 \mathrm{~cm}) ; 2=$ Analcime (Sample 418A-35-2, 39-40 $\mathrm{cm}$ ); 3 = Phillipsite (Specimen 418A-65-1, $125 \mathrm{~cm}$ ); 4 = Apophyllite (Specimen 418A-65-1, $125 \mathrm{~cm}) ; 5=$ Zeolite with a structure resembling that of the gismondine-gmelinite group, but with a high $\mathrm{K}_{2} \mathrm{O}$ and very low $\mathrm{CaO}$ content (Sample $417 \mathrm{~A}-30-5,67-73 \mathrm{~cm}$ ); $6=\mathrm{K}$ feldspar (Sample 417A-26-4, 90-92 cm); $d / n=$ spacing in $A ; 1=$ intensity; $x=$ Reflection of calcite; $\mathrm{b}=$ Broad reflections; $\mathrm{d}=$ Double reflections. 


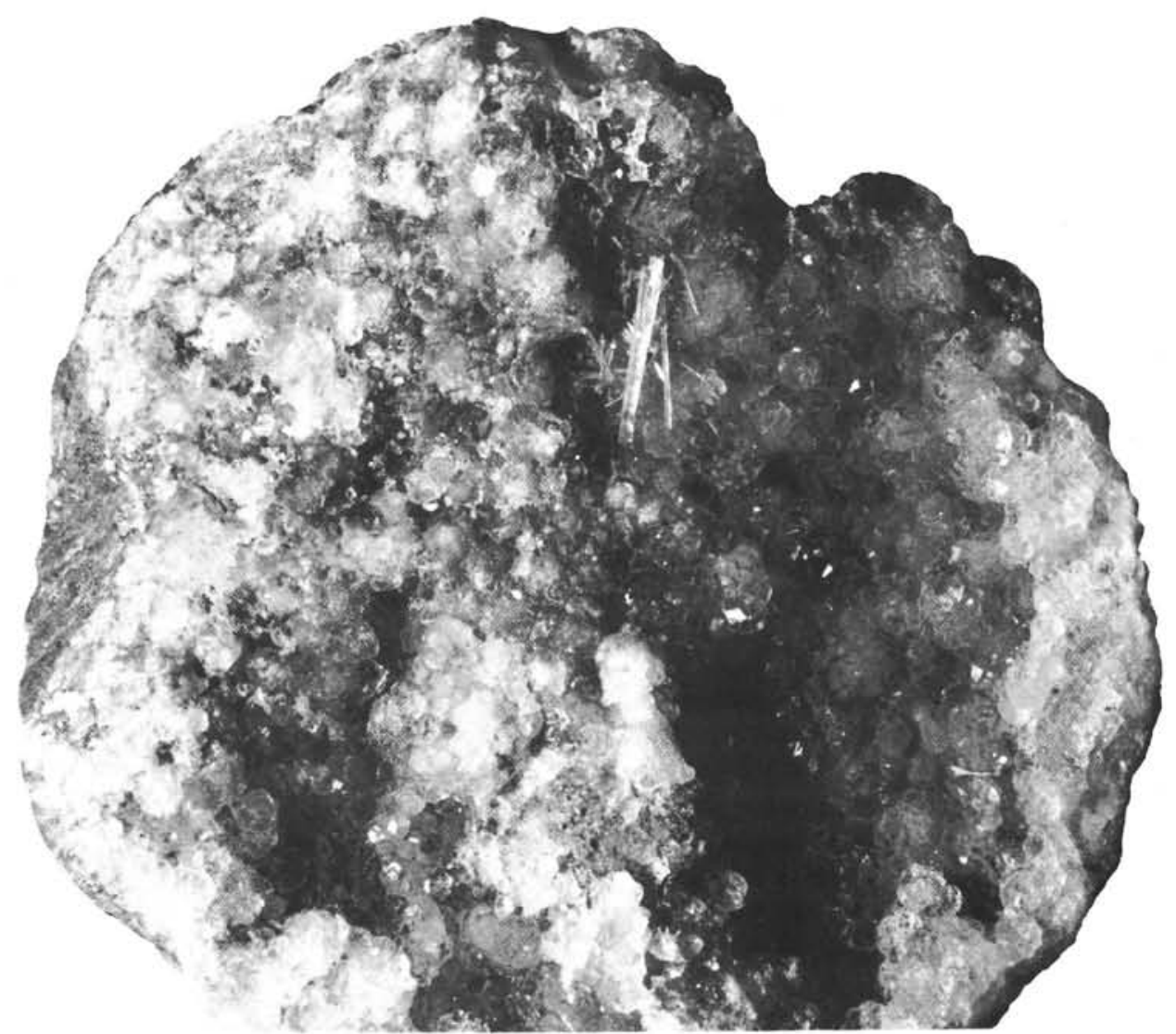

Figure 4. Crystals of analcime and natrolite in a basalt cavity; $417 A-39-1,85-90 \mathrm{~cm}$.

rocks. One sample from Hole 417A (Section 34-1, Piece 5) is different from the others in that most of its plagioclase phenocrysts and microlites are replaced by natrolite, and its $\mathrm{Na}_{2} \mathrm{O}$ content reaches 4.90 per cent. The sample also contains K-feldspar and much celadonite, accounting for a high $\mathrm{K}_{2} \mathrm{O}$ content ( 3.04 per cent) and a high degree of iron oxidation $\left[\mathrm{f}=83\right.$ per cent, where $\left.\mathrm{f}=\mathrm{Fe}_{2} \mathrm{O}_{3} /\left(\mathrm{Fe}_{2} \mathrm{O}_{3}+\mathrm{FeO}\right)\right]$. In cavities, analcime crystals grow over walls lined with clay minerals (montmorillonite or its mixture with celadonite). In the centers of such cavities, analcime crystals are occasionally overgrown by acicular natrolite crystals. Microveinlets consist of analcime alone or, more often, of analcime and montmorillonite or analcime and celadonite assemblages. In such veinlets, analcime comprises the cores, with the margins consisting of celadonite. In plagioclase phenocrysts, analcime replaces the cores. Possibly, it fills the cavities formed previously by the solution of plagioclase. In cases of strong alteration, chalcedony skeletons (rims and partitions which are made up of chalcedony with cavities interspersed) remain in the place of phenocrysts. The skeletons are partially filled with analcime. Also, analcime occurs in fissures running across plagioclase crystals, frequently in association with natrolite.

A close association of analcime with celadonite was observed in a sample from Hole 417A (Section 38-5, Piece $5 \mathrm{E})$, where analcime is substituted for glass along the contact between a breccia and oxidized basalt. Celadonite forms globular spherulites scattered in the bases which are composed of analcime. Therefore, analcime seems to be formed somewhat later than clay minerals and chalcedony, simultaneous with or somewhat earlier than natrolite.

In one instance (Specimen 418A-38-1, 3 cm) we observed that a hyaloclastic breccia between pillows contains fragments of glass substituted by smectite, the cement consisting of euhedral minute crystals of analcime and calcite. Some of the calcite crystals are entrapped by larger analcime crystals (Plate 3, Figure 1).

Natrolite occurs in acicular crystals along with analcime in druses and in plagioclase phenocrysts. It was identified by X-ray analysis (Table 2). Less widespread than analcime, it was found at a greater depth in Hole 417A (110 m below basalt basement).

Phillipsite is the most widespread zeolite in Hole 418A and is also abundant in Hole $417 \mathrm{~A}$, but was not found in Hole 417D. Onboard ship during Legs 52 and 53, we mistakenly identified it as mordenite, but after laboratory X-ray analysis, corrected the identification (Table 2). Phillipsite is most common in the altered breccias of vitreous edges of pillow lavas. There it occurs as pink colored crystalline grains reaching several millimeters in size, along with smectite, celadonite, calcite, and, occasionally, quartz. The bright pink color of the mineral is likely to be produced by a fine admixture of iron hydroxides. The mineral is found in the interpillow breccia in a form of stellar aggregates of radiated veinlets. In the brecciated glass, it often forms pseudomorphs after plagioclase phenocrysts. Plagioclase 
relicts are sometimes found in phillipsite grains, whereas fresh plagioclase phenocrysts are never seen in such brecciated glass (Plate 3, Figure 2).

Phillipsite occurs more rarely in highly altered patches among poorly altered basalts. It forms pseudomorphs after plagioclase phenocrysts, as observed in a specimen from Hole 418A (Sample 83-4, 8-11 cm). The index of refraction measurement, using samples from different levels of Hole $418 \mathrm{~A}$, yielded identical results; $\gamma=1.479, \alpha=1.476$ \pm 0.002 .

Microprobe analysis and X-ray data of the mineral are given in Tables 1 and 2 . The composition of phillipsite was not quite common; its distinctive features are an extremely low $\mathrm{CaO}$ content and a predominance of $\mathrm{Na}_{2} \mathrm{O}$ over $\mathrm{K}_{2} \mathrm{O}$. This distinguishes it from the more common phillipsite of Leg 37 (Robinson et al., 1977).

Oxide minerals are represented predominantly by hydroxides of iron and, probably, manganese. The formation of hydroxides is related mainly to the decomposition of glass and groundmass accompanied by oxidation of ferrous iron. Iron hydroxides in the groundmass appear along fractures and brecciated zones as near-vein alteration products. Such oxidation is correlated with the formation of K-feldspar pseudomorphs and plagioclase. Iron hydroxides (hydrogoethite according to microprobe determination) are also found in veinlets along with celadonite (partially replacing it) and calcite. Iron hydroxides are rarely found at the lower intervals of the drill holes.

Manganese oxides (black in thin sections) are very scarce. They are seen in rhythmically banded agate-like accumulations among celadonite and smectite fillings of veins and vesicles at the upper levels of Holes 417D and 418A (Plate 1, Figure 1).

Secondary sulfides are represented mainly by pyrite and, more rarely, by marcasite and chalcopyrite. No regularities were established in the distribution of secondary sulfides with depth or in the correlation with other secondary minerals. Almost every sample of altered basalts was found to contain secondary sulfides. There are intervals where they are abundant or seen macroscopically and intervals where they are virtually absent. The latter applies to Unit 10 of Hole 418A and to the coarse-grained, poorly altered basalts or highly oxidized basalts with $\mathrm{K}$-feldspar.

Pyrite occurs in pyrite veinlets or in veins composed of clay minerals, carbonates, and quartz (Plate 3, Figures 3 and 4) as irregular grains disseminated in the altered groundmass (usually with smectite) and as well-shaped crystals in the groundmass smectite (Plate 4, Figure 1). In some cases, it is seen that secondary sulfides are developed along with magnetite replacement (Plate 4, Figure 2). More frequently, sulfides are developed independently from magnetite, using the iron of the decomposing glass or silicates. Where the rock is abundant in pyrite, magnetite is absent. Secondary sulfides are often found in rims of vesicles, either comprising the fillings of the latter, or forming pyrite menisci (Plate 4, Figure 3).

Palagonite is widespread at the chilled edges of pillow lavas. It is developed after glass (not everywhere). Its color and index of refraction are identical to those of brown and green smectites. The microprobe analysis of the palagonite composition (described by Rusinov et al., this volume) revealed its analogy with smectites.

\section{RELATIONS OF PRIMARY MINERALS AND VOLCANIC GLASSES WITH ALTERATION PRODUCTS}

Olivine is most liable to alteration. Its relicts are preserved only at rare intervals in coarse-crystalline (holocrystalline) basalts inside smectite pseudomorphs after olivine phenocrysts. Such intervals are encountered in both the lower and upper parts of Holes 417D and 418A. Microprobe analysis data of olivine and smectite developed after olivine (Table 3) permit calculation of the substance balance (with regard to the difference in volume weights). In the substitution of forsterite by smectite, every unit of volume loses 5 to 6 per cent iron hydroxides (percentage of the original olivine weight), nearly all the manganese $(0.2$ per cent $\mathrm{MnO}$ ), a large percentage of magnesium (29 per cent $\mathrm{MgO}$ ), and a small percentage of $\mathrm{SiO}_{2}$ (3 per cent). On the other hand, the following constituents are added: $\mathrm{K}_{2} \mathrm{O}(0.16$ per cent), $\mathrm{Na}_{2} \mathrm{O}$ (0.05 per cent), $\mathrm{CaO}$ ( 0.2 per cent), all $\mathrm{Al}_{2} \mathrm{O}_{3}$ and all water ( 7 to 10 per cent). In this case, the smectite developed after olivine is low in $\mathrm{Al}_{2} \mathrm{O}_{3}$. In other cases, the $\mathrm{Al}_{2} \mathrm{O}_{3}$ content in smectite averages 10 per cent and the total subtraction of magnesium and iron is considerably higher.

The massive volcanic glass found at chilled edges often remains fresh. It is palagonitized along fractures, veinlets, and fragment contacts. In contrast, the glass occurring together with the fine crystalline groundmass (inside the pillows and particularly in zones adjacent to the glassy edges) is usually totally replaced by clay minerals. It is likely that the fine crystalline groundmass with minute glass aggregates was permeable easily to solutions, whereas the massive glass passed solutions only along fractures.

The calculation of the substance balance in the substitution of glass by smectite accompanied by vesicle filling, assuming that glass accounts for 10 per cent and vesicles for 2 per cent of the basalt volume, reveals a relatively low subtraction of $\mathrm{SiO}_{2}$, perceptible subtraction of $\mathrm{Al}_{2} \mathrm{O}_{3}, \mathrm{TiO}_{2}$, $\mathrm{CaO}$, and $\mathrm{Na}_{2} \mathrm{O}$; and considerable addition of $\mathrm{MgO}, \mathrm{K}_{2} \mathrm{O}$,

TABLE 3

Microprobe Analyses of Olivine Relicts and Smectite From an Olivine Phenocryst

\begin{tabular}{lccr}
\hline Oxides & 1 & 2 & \multicolumn{1}{c}{3} \\
\hline $\mathrm{SiO}_{2}$ & 39.06 & 38.93 & 52.51 \\
$\mathrm{Al}_{2} \mathrm{O}_{3}$ & - & - & 0.03 \\
$\mathrm{FeO}$ & 12.04 & 15.36 & 9.77 \\
$\mathrm{MnO}$ & 0.17 & 0.24 & 0.01 \\
$\mathrm{MgO}$ & 45.73 & 43.20 & 24.64 \\
$\mathrm{CaO}$ & 0.24 & 0.23 & 0.55 \\
$\mathrm{~K}_{2} \mathrm{O}$ & - & - & 0.12 \\
$\mathrm{Na}_{2} \mathrm{O}$ & - & - & 0.06 \\
Total & 97.23 & 97.97 & 87.69 \\
\hline
\end{tabular}

Note: 1,2 = Relicts of olivine; 3 = Smectite dividing olivine (Specimen 418A-85-1, $33 \mathrm{~cm}$ ). Analyst: I.P. Laputina. 
and $\mathrm{H}_{2} \mathrm{O}$. Since olivine in the groundmass and in phenocrysts (total of 10 per cent) is also substituted by smectite, it is obvious that the $\mathrm{MgO}$ supply in smectites developed after glass is mainly balanced out by the $\mathrm{MgO}$ subtraction in olivine substitution. Evidently, the $\mathrm{Al}_{2} \mathrm{O}_{3}$ subtraction is also compensated for. The $\mathrm{SiO}_{2}$ loss is likely to be partially compensated for by the formation of quartz and chalcedony in veinlets, vesicles, and cavities. The $\mathrm{CaO}$ subtraction is accompanied by the formation of calcite in the altered basalt.

The alteration of the chemical composition of holocrystalline basalts, where smectite is developed only after olivine, is totally different from that of the basalts containing glass in the groundmass. In holocrystalline basalts, the alteration of olivine involves the loss of 1 to 2 per cent $\mathrm{MgO}, 0.5$ per cent $\mathrm{FeO}$, and 0.5 per cent $\mathrm{SiO}_{2}$, and the supply of 1 per cent $\mathrm{Al}_{2} \mathrm{O}_{3}, 1$ per cent $\mathrm{H}_{2} \mathrm{O}$, and 0.03 to 0.05 per cent $\mathrm{K}_{2} \mathrm{O}$. The basalt containing 10 per cent glass, 10 per cent olivine, and 2 per cent vesicles loses about 0.15 per cent $\mathrm{TiO}_{2}, 0.2$ to 0.5 per cent $\mathrm{MgO}$, about 0.2 per cent $\mathrm{Na}_{2} \mathrm{O}$, about 1 per cent $\mathrm{CaO}$, about 0.1 per cent $\mathrm{MnO}$, and adds 0.05 per cent $\mathrm{K}_{2} \mathrm{O}$ and 1.5 to 2 per cent $\mathrm{H}_{2} \mathrm{O}$.

Thus, the general trend in the substance exchange of the moderately altered basalts drilled on these legs is the supply to the ocean of calcium, magnesium, manganese, sodium, titanium, and the extraction of water and $\mathrm{K}_{2} \mathrm{O}$ from the solutions.

Plagioclases in intensely altered basalts are also altered. They are replaced by light colored smectite, calcite, and, at the intervals of highly oxidized basalts at the top of the series, by $\mathrm{K}$-feldspar and phillipsite.

Minute veinlets of colorless or light colored smectite and pyrite are occasionally observed in plagioclase phenocrysts in relatively poorly altered basalts.

Clinopyroxenes do not manifest any specific alterations; they are fairly resistant to low-temperature actions. In highly altered basalt, the clinopryoxene of the groundmass is altered together with the other minerals.

The most important basalt alteration is the decomposition of glass and substitution of olivine and plagioclase phenocrysts. This alteration involves the subtraction of $\mathrm{CaO}$ and $\mathrm{Na}_{2} \mathrm{O}$, the supply of $\mathrm{K}_{2} \mathrm{O}$, and intensification of oxidation. The higher the content of newly formed minerals in the rock (estimated by the area in thin sections), the lower the $\mathrm{CaO}$ content is. This relationship holds well for the rocks of Hole $417 \mathrm{~A}$ and is attributed to the fact that in the substitution of glass and phenocrysts, calcium-lacking minerals are formed predominantly: celadonite, smectites, K-feldspar, and, more rarely, analcime.

Calcite is commonly found in veins, veinlets, and vesicles. Most of the samples analyzed were selected so that they did not contain veinlets and large vesicles. Where calcite was present, the related calcium could be accounted for by the $\mathrm{CO}_{2}$ content in the analysis. Consequently, the $\mathrm{CaO}$ loss can be considered as the main tendency in the alteration of the chemical composition of basalt. The $\mathrm{CaO}$ content in the rocks, as determined by bulk chemical analyses (Tables 4 and 5), can be adopted as the criterion for basalt freshness (the higher the $\mathrm{CaO}$ content, the fresher the basalt, and vice versa).
For the basalts of Leg 37 (Robinson et al., 1977), an attempt was made to prove the dependence of chemical alteration in the rocks upon their degree of hydration by plotting various diagrams of their relationship. However, such diagrams, as well as chemical composition-versusdepth plots, are unsatisfactory for the basalts of Legs 51 through 53. This is because one of the principal secondary minerals is the anhydrous mineral, $\mathrm{K}$-feldspar, and an increase in the $\mathrm{K}_{2} \mathrm{O}$ content is independent of the water content of the rock. Variation diagrams with $\mathrm{CaO}$ contents plotted on the abscissa are more representative in this respect; they help to establish some regularities. For example, as the $\mathrm{CaO}$ content in the rocks of Hole $417 \mathrm{~A}$ decreases, the $\mathrm{K}_{2} \mathrm{O}$ content increases (Figure 5). The higher the $\mathrm{K}_{2} \mathrm{O}$ content, the broader is the range of its possible variation. In the most altered basalts the $\mathrm{K}_{2} \mathrm{O}$ content varies from 3 to 9 per cent. In unaltered basalts where $\mathrm{CaO}$ reaches 13 to 14 per cent, the $\mathrm{K}_{2} \mathrm{O}$ content does not exceed 1 per cent and in most of the samples is below 0.5 per cent. In samples showing a $\mathrm{K}_{2} \mathrm{O}$ content higher than 0.5 per cent, the basalt was slightly altered with the formation of $\mathrm{K}$-feldspar at the expense of the sodic rims of plagioclase phenocrysts and celadonite filling vesicles without any perceptible subtraction of $\mathrm{CaO}$. Some points of the altered basalts indicating extremely low $\mathrm{K}_{2} \mathrm{O}$ contents correspond to the samples in which plagioclase phenocrysts were substituted by potassium-poor smectite (montmorillonite) or analcime and zeolites, rather than by K-feldspar. This is applied to the basalts from Hole 417D in which the $\mathrm{K}_{2} \mathrm{O}$ content, though increasing with decreasing $\mathrm{CaO}$, is much lower than in the basalts from Hole $417 \mathrm{~A}$, and $\mathrm{K}_{2} \mathrm{O}$ does not exceed 2 per cent in the most altered rocks $(\mathrm{CaO}=1$ to 2 per cent) (Figure 6$)$. As the $\mathrm{CaO}$ content increases (about 10 to 14 per cent), i.e., approaching that of fresh basalts, both tendencies (of Holes 417A and 417D) converge, and the $\mathrm{K}_{2} \mathrm{O}$ contents for poorly altered and unaltered rocks are nearly identical ( 0.1 to 0.3 per cent).

In contrast to $\mathrm{K}_{2} \mathrm{O}, \mathrm{Na}_{2} \mathrm{O}$ exhibits a direct dependence on the $\mathrm{CaO}$ content (Figure 7). The highest contents are found in the unaltered basalts ( 2.1 to 2.3 per cent). In the altered rocks, the contents are lower. In general, at the early stage of alteration $(\mathrm{CaO}=7$ to 14 per cent $)$, the $\mathrm{Na}_{2} \mathrm{O}$ content remains at about the same level as that of fresh basalts being concentrated in some smectites and partially in analcime and zeolites. At more intense alteration, these minerals become unstable, and the $\mathrm{Na}_{2} \mathrm{O}$ content decreases markedly, reaching 1 per cent in the most altered rocks. As seen from Figure 7, several points indicate extremely high $\mathrm{Na}_{2} \mathrm{O}$ contents at an interval of 4 to 7 per cent $\mathrm{CaO}$. These points correspond to the samples in which plagioclase phenocrysts are replaced predominantly by analcime, and occasionally with natrolite. These newly formed minerals form veinlets in the rock.

An illustrative factor is the degree of iron oxidation, $f=$ $\mathrm{Fe}_{2} \mathrm{O}_{3} /\left(\mathrm{Fe}_{2} \mathrm{O}_{3}+\mathrm{FeO}\right)$, which varies greatly, from 0.1 to 1.0. The highest degree of oxidation, when nearly all iron is represented by ferric oxide, is observed in the most altered rocks with $\mathrm{CaO}=1$ to 4 per cent (Figure 8 ). In moderately altered rocks $(\mathrm{CaO}=4$ to 10 per cent $)$, the $\mathrm{f}$ value decreases with increasing $\mathrm{CaO}$. With some exceptions, the $\mathrm{f}-\mathrm{CaO}$ rela- 
TABLE 4

Chemical Analyses of Basalts From Holes 417A and 417D

\begin{tabular}{|c|c|c|c|c|c|c|c|c|c|c|c|c|c|c|c|c|}
\hline Oxides & 1 & 2 & 3 & 4 & 5 & 6 & 7 & 8 & 9 & 10 & 11 & 12 & 13 & 14 & 15 & 16 \\
\hline $\mathrm{SiO}_{2}$ & 44.06 & 46.44 & 47.00 & 45.00 & 46.00 & 48.00 & 46.32 & 46.40 & 48.48 & 45.34 & 40.60 & 45.82 & 43.64 & 47.00 & 47.00 & 46.98 \\
\hline $\mathrm{TiO}_{2}$ & 1.40 & 1.44 & 1.40 & 1.42 & 1.64 & 1.40 & 1.48 & 1.40 & 1.46 & 1.44 & 0.88 & 1.35 & 1.08 & 1.28 & 1.48 & 1.45 \\
\hline $\mathrm{Al}_{2} \mathrm{O}_{3}$ & 15.42 & 16.52 & 16.80 & 17.00 & 15.37 & 16.45 & 16.60 & 16.54 & 16.71 & 15.00 & 9.74 & 15.45 & 10.60 & 16.10 & 15.00 & 14.60 \\
\hline $\mathrm{Fe}_{2} \mathrm{O}_{3}$ & 7.70 & 9.05 & 4.40 & 6.70 & 9.71 & 3.68 & 7.83 & 3.87 & 3.23 & 4.74 & 5.96 & 5.70 & 7.40 & 4.75 & 8.45 & 7.18 \\
\hline $\mathrm{FeO}$ & 3.17 & 1.62 & 4.75 & 2.00 & 2.00 & 5.26 & 3.34 & 4.60 & 6.50 & 5.36 & 3.70 & 4.63 & 3.32 & 4.93 & 3.62 & 4.00 \\
\hline $\mathrm{MnO}$ & 0.18 & 0.23 & 0.21 & 0.11 & 0.10 & 0.18 & 0.15 & 0.21 & 0.16 & 0.23 & 0.24 & 0.17 & 0.06 & 0.26 & 0.15 & 0.18 \\
\hline $\mathrm{MgO}$ & 5.80 & 4.40 & 6.35 & 4.90 & 3.27 & 6.70 & 5.48 & 6.16 & 6.53 & 6.22 & 8.88 & 6.00 & 9.55 & 6.32 & 6.66 & 6.64 \\
\hline $\mathrm{CaO}$ & 10.72 & 6.58 & 12.68 & 10.77 & 4.62 & 12.57 & 11.15 & 13.93 & 12.08 & 13.49 & 10.83 & 13.44 & 6.25 & 12.90 & 10.34 & 11.97 \\
\hline $\mathrm{Na}_{2} \mathrm{O}$ & 2.01 & 1.95 & 2.38 & 2.29 & 4.90 & 2.37 & 2.38 & 2.20 & 2.28 & 2.38 & 2.06 & 2.32 & 1.71 & 2.19 & 2.47 & 2.29 \\
\hline $\mathrm{K}_{2} \mathrm{O}$ & 2.02 & 4.33 & 0.20 & 1.69 & 3.04 & 0.13 & 1.05 & 0.08 & 0.10 & 0.44 & 1.65 & 0.40 & 1.22 & 0.24 & 0.59 & 0.43 \\
\hline $\mathrm{H}_{2} \mathrm{O}^{-}$ & 1.72 & 2.13 & 1.97 & 2.46 & 3.23 & 1.55 & 1.53 & 1.59 & 0.80 & 1.16 & 4.41 & 1.57 & 6.50 & 1.45 & 1.69 & 1.32 \\
\hline $\mathrm{H}_{2}^{+} \mathrm{O}^{+}$ & 2.45 & 3.21 & 0.94 & 2.33 & 5.10 & 0.60 & 1.60 & 0.82 & 0.66 & 1.25 & 3.57 & 0.98 & 5.32 & 0.85 & 1.57 & 1.25 \\
\hline $\mathrm{CO}_{2}$ & 2.20 & 0.90 & 0.38 & 2.16 & 0.20 & 0.40 & 0.60 & 1.74 & 0.10 & 2.42 & 6.95 & 2.00 & 3.14 & 1.30 & 0.70 & 1.21 \\
\hline L.I. & 1.00 & 1.00 & - & 0.65 & 0.50 & - & - & - & 0.42 & - & - & - & - & - & - & - \\
\hline Total & 99.85 & 99.80 & 99.46 & 99.48 & 99.68 & 99.49 & 99.51 & 99.54 & 99.51 & 99.47 & 99.47 & 99.83 & 99.79 & 99.57 & 99.71 & 99.50 \\
\hline
\end{tabular}

Note: $1=$ Basalt, moderately altered (Sample 417A-24-5, 5-8 cm);2 = Basalt, strongly altered (Section 417A-26-5, Piece 1); $3=$ Basalt, weakly altered (Section 417A-30-1, Piece 1); 4 = Basalt, moderately altered (Section 417A-31-1, Piece 1); $5=$ Basalt, badly altered (Section 417A-34-1, Piece 5); $6=$ Basalt, unaltered (Section 417A-34-2, Piece 8B); 7 = Basalt, weakly altered (Section 417A-35-2, Piece 7); $8=$ Basalt, unaltered (Section 417A-41-4, Piece 2); 9 = Basalt, unaltered (Section 417A-44-2, Piece 4A); 10 = Basalt, weakly altered (Section 417D-22-4, Piece 6); $11=$ Glassy basalt, moderately altered (Section 417D-26-1, Piece 4); 12 = Basalt, weakly altered (Section 417D-27-1, Piece 5); $13=$ Breccia $($ Section 417D-35-7, Piece 5); 14 = Basalt, unaltered (Section 417D-40-3, Piece 2B); 15 = Basalt, weakly altered (Section 417D-43 3, Piece 1C); 16 = Basalt, moderately altered (Section 417D44-2, Piece 1A). L.I. = Lost after ignition. Analysts: E.P. Frolova and L.P. Nekrasova.

TABLE 5

Spectral Analyses of Basalts From Holes 417A and 417 ${ }^{a}$

\begin{tabular}{|c|c|c|c|c|c|c|c|c|c|c|c|c|c|c|c|c|}
\hline Elements & 1 & 2 & 3 & 4 & 5 & 6 & 7 & 8 & 9 & 10 & 11 & 12 & 13 & 14 & 15 & 16 \\
\hline $\mathrm{Be}$ & $10^{-4}$ & $7 \times 10^{-5}$ & $7 \times 10^{-5}$ & $7 \times 10^{-5}$ & $7 \times 10^{-5}$ & $10^{-4}$ & $10^{-4}$ & $7 \times 10^{-5}$ & $7 \times 10^{-5}$ & $7 \times 10^{-5}$ & $0 \times 0$ & $7 \times 10^{-5}$ & $7 \times 10^{-5}$ & $7 \times 10^{-5}$ & $10^{-4}$ & $10^{-4}$ \\
\hline $\mathrm{Sc}$ & $3 \times 10^{-3}$ & $3 \times 10^{-3}$ & $3 \times 10^{-3}$ & $3 \times 10^{-3}$ & $3 \times 10^{-3}$ & $3 \times 10^{-3}$ & $3 \times 10^{-3}$ & $3 \times 10^{-3}$ & $3 \times 10^{-3}$ & $3 \times 10^{-3}$ & $3 \times 10^{-3}$ & $3 \times 10^{-3}$ & $3 \times 10^{-3}$ & $4 \times 10^{-3}$ & $4 \times 10^{-3}$ & $3 \times 10^{-3}$ \\
\hline $\mathrm{Pb}$ & $10^{-3}$ & $10^{-3}$ & $10^{-3}$ & $10^{-3}$ & $10^{-3}$ & $10^{-3}$ & $10^{-3}$ & $10^{-3}$ & $0 \times 0$ & $0 \times 0$ & $0 \times 0$ & $0 \times 0$ & $10^{-3}$ & $0 \times 0$ & $10^{-3}$ & $0 \times 0$ \\
\hline $\mathrm{Ga}_{3}$ & $2 \times 10^{-3}$ & $3 \times 10^{-3}$ & $3 \times 10^{-3}$ & $3 \times 10^{-3}$ & $1.5 \times 10^{-3}$ & $2 \times 10^{-3}$ & $3 \times 10^{-3}$ & $3 \times 10^{-3}$ & $3 \times 10^{-3}$ & $2 \times 10^{-3}$ & $1.5 \times 10^{-3}$ & $2 \times 10^{-3}$ & $1.5 \times 10^{-3}$ & $2 \times 10^{-3}$ & $2 \times 10^{-3}$ & $2 \times 10^{-3}$ \\
\hline v & $10^{-2}$ & $10^{-2}$ & $10^{-2}$ & $10^{-2}$ & $3 \times 10^{-2}$ & $10^{-2}$ & $10^{-2}$ & $10^{-2}$ & $10^{-2}$ & $10^{-2}$ & $3 \times 10^{-2}$ & $10^{-2}$ & $3 \times 10^{-2}$ & $10^{-2}$ & $10^{-2}$ & $10^{-2}$ \\
\hline $\mathrm{Cu}$ & $10^{-3}$ & $10^{-2}$ & $10^{-2}$ & $10^{-2}$ & $10^{-3}$ & $10^{-2}$ & $10^{-2}$ & $10^{-2}$ & $10^{-2}$ & $10^{-2}$ & $10^{-3}$ & $10^{-2}$ & $10^{-2}$ & $10^{-2}$ & $10^{-2}$ & $10^{-2}$ \\
\hline $\mathrm{Zn}$ & $10^{-2}$ & $10^{-2}$ & $10^{-2}$ & $10^{-2}$ & $10^{-2}$ & $10^{-2}$ & $10^{-2}$ & $10^{-2}$ & $10^{-2}$ & $10^{-2}$ & $10^{-3}$ & $10^{-2}$ & $10^{-2}$ & $10^{-2}$ & $10^{-2}$ & $10^{-2}$ \\
\hline Co & $3 \times 10^{-3}$ & $3 \times 10^{-3}$ & $3 \times 10^{-3}$ & $3 \times 10^{-3}$ & $3 \times 10^{-3}$ & $3 \times 10^{-3}$ & $3 \times 10^{-3}$ & $3 \times 10^{-3}$ & $3 \times 10^{-3}$ & $3 \times 10^{-3}$ & $3 \times 10^{-3}$ & $3 \times 10^{-3}$ & $3 \times 10^{-3}$ & $3 \times 10^{-3}$ & $3 \times 10^{-3}$ & $3 \times 10^{-3}$ \\
\hline $\mathrm{Ni}$ & $10^{-3}$ & $10^{-3}$ & $10^{-2}$ & $10^{-3}$ & $10^{-3}$ & $10^{-2}$ & $10^{-3}$ & $10^{-2}$ & $10^{-2}$ & $10^{-2}$ & $10^{-3}$ & $10^{-2}$ & $10^{-3}$ & $10^{-2}$ & $10^{-2}$ & $10^{-3}$ \\
\hline $\mathrm{Zr}$ & $10^{-2}$ & $10^{-2}$ & $10^{-2}$ & $10^{-2}$ & $10^{-2}$ & $10^{-2}$ & $10^{-2}$ & $10^{-2}$ & $10^{-2}$ & $10^{-2}$ & $10^{-2}$ & $2 \times 10^{-2}$ & $10^{-2}$ & $2 \times 10^{-2}$ & $10^{-2}$ & $10^{-2}$ \\
\hline $\mathrm{Cr}$ & $3 \times 10^{-2}$ & $3 \times 10^{-2}$ & $3 \times 10^{-2}$ & $3 \times 10^{-2}$ & $3 \times 10^{-2}$ & $3 \times 10^{-2}$ & $3 \times 10^{-2}$ & $3 \times 10^{-2}$ & $3 \times 10^{-2}$ & $3 \times 10^{-2}$ & $10^{-2}$ & $3 \times 10^{-2}$ & $3 \times 10^{-2}$ & $3 \times 10^{-2}$ & $3 \times 10^{-2}$ & $3 \times 10^{-2}$ \\
\hline St & $2 \times 10^{-2}$ & $2 \times 10^{-2}$ & $2 \times 10^{-2}$ & $2 \times 10^{-2}$ & $2 \times 10^{-2}$ & $2 \times 10^{-2}$ & $2 \times 10^{-2}$ & $2 \times 10^{-2}$ & $2 \times 10^{-2}$ & $2 \times 10^{-2}$ & $2 \times 10^{-2}$ & $2 \times 10^{-2}$ & $2 \times 10^{-2}$ & $2 \times 10^{-2}$ & $2 \times 10^{-2}$ & $2 \times 10^{-2}$ \\
\hline $\mathrm{Ba}$ & $10^{-3}$ & $1 \sigma^{-3}$ & $10^{-3}$ & $10^{-3}$ & $10^{-3}$ & $10^{-3}$ & $10^{-3}$ & $10^{-3}$ & $10^{-3}$ & $10^{-3}$ & $10^{-3}$ & $10^{-3}$ & $10^{-3}$ & $10^{-3}$ & $10^{-3}$ & $10^{-3}$ \\
\hline B & $3 \times 10^{-3}$ & $10^{-3}$ & $10^{-4}$ & $3 \times 10^{-3}$ & $3 \times 10^{-3}$ & $10^{-3}$ & $10^{-3}$ & $10^{-4}$ & $10^{-4}$ & $10^{-3}$ & $10^{-3}$ & $3 \times 10^{3}$ & $3 \times 10^{-3}$ & $3 \times 10^{-3}$ & $3 \times 10^{-3}$ & $3 \times 10^{-3}$ \\
\hline $\mathrm{Y}$ & $3 \times 10^{-3}$ & $3 \times 10^{-3}$ & $3 \times 10^{-3}$ & $3 \times 10^{-3}$ & $3 \times 10^{-3}$ & $3 \times 10^{-3}$ & $3 \times 10^{-3}$ & $3 \times 10^{-4}$ & $3 \times 10^{-3}$ & $3 \times 10^{-3}$ & $3 \times 10^{-3}$ & $3 \times 10^{-3}$ & $3 \times 10^{-3}$ & $3 \times 10^{-3}$ & $3 \times 10^{-3}$ & $3 \times 10^{-3}$ \\
\hline
\end{tabular}

Note: $1=$ Basalt, moderately altered (Sample 417A-24-5, 5-8 cm);2 = Basalt, strongly altered (Section 417A-26-5, Piece 1);3 = Basalt, weakly altered (Section $417 \mathrm{~A}-30-1$, Piece 1); $4=$ Basalt, moderately al tered (Section $417 \mathrm{~A}-31-1$, Piece 1); 5 = Basalt, badly altered (Section 417A-34-1, Piece 5); $6=$ Basalt, unaltered (Section 417A-34-2, Piece 8B); $7=$ Basalt, weakly altered (Section 417A-35-2, Piece 7); $8=$ Basalt, unaltered (Section 417A-41-4, Piece 2); $9=$ Basalt, unaltered (Section $417 \mathrm{~A}-44-2$, Piece $4 \mathrm{~A}) ; 10=$ Basalt, weakly altered $($ Section $417 \mathrm{D}-22-4$, Piece 6); $11=$ Glassy basalt, moderately altered $($ Section $417 \mathrm{D}-26-1$,
Piece 4 ; $12=$ Basalt, 43-3, Piece $1 \mathrm{C}) ; 16=$ Basalt, moderately altered (Section 417D-44-2, Piece $1 \mathrm{~A})$.

${ }^{a}$ Contents of elements are in wt. \%. Elements not mentioned were not detected.

tionship approaches a linear one. The $f$ value remains at about 0.7 (ferric prevails over ferrous iron) at higher $\mathrm{CaO}$ contents (in poorly altered basalts). In unaltered or nearly unaltered basalts with $\mathrm{CaO}=12$ to 14 per cent, the $\mathrm{f}$ value varies from 0.3 to 0.65 . This variation is likely to be attributed to different conditions of lava solidification: $f$ is higher in vesicular slag-like basalts and lower in holocrystalline varieties. Three points stand apart in Figure 8, corresponding to the moderately altered basalts. The latter are characterized by an extremely low degree of iron oxidation ( $f=0.15$ to 0.25 ), which is much lower than in the unaltered rocks. Here, the ferrous iron is fixed in ferromagnesian smectite which substitutes glass. Thus, patches of a more reducing environment are noted against a normal background of general oxidation in the course of secondary alteration of basalts. This indicates the presence of local Eh and probably $\mathrm{pO}_{2}$ gradients, and hence some inertness of oxygen in the alteration process.

Four groups of points are distinguished according to $f$ values: (1) highly altered basalts with $\mathrm{f}$ about 1 ; (2) moderately altered basalts with $\mathrm{f}=0.7$ to 0.9 ; (3) poorly altered and unaltered basalts with $f=0.35$ to 0.65 ; (4) basalts moderately altered in a reduction environment, with $\mathrm{f}=$ 0.15 to 0.25 . The fourth group stands apart corresponding to the basalts altered under reducing conditions. Groups 1 and 2 , having a comparatively high $\mathrm{f}$, correspond to an interval of Figure 8 where alteration of rocks is accompanied by sodium loss. Yet, the above-mentioned tendencies are not always valid. The most pronounced variation in f occurs at $\mathrm{CaO}=5$ to 9 per cent; i.e., at a fairly early stage of alteration. On the other hand, the dependence of the $\mathrm{Na}_{2} \mathrm{O}$ content upon $\mathrm{CaO}$ is most evident between 1 to 5 per 


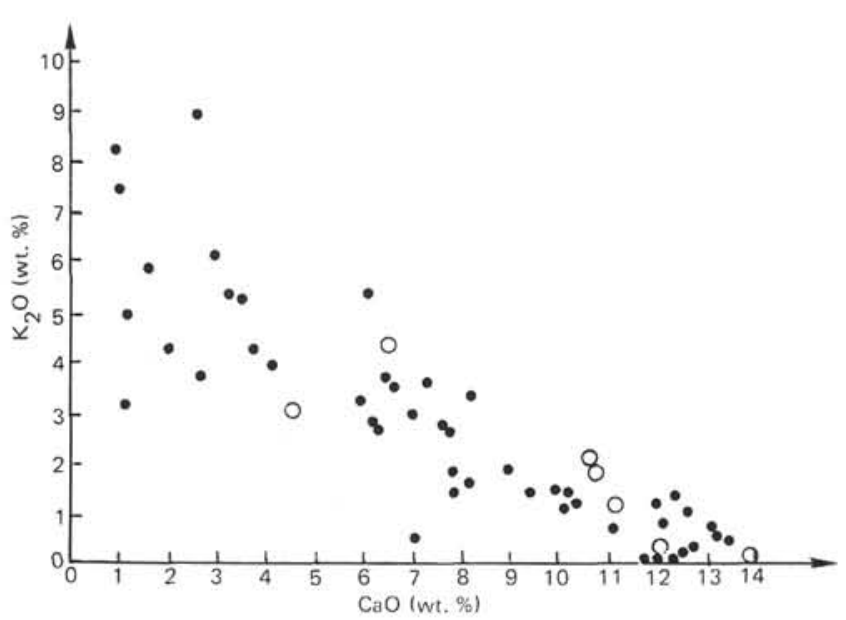

Figure 5. The diagram $\mathrm{CaO}-\mathrm{K}_{2} \mathrm{O}$ for basalts from Hole 417 A. Oxide content in wt. \%. Open circles - analyses from Table 4, filled circles $\mathrm{CaO}$ - content excluding $\mathrm{CaCO}_{3}$ (here and Fig. 6, 7, 8) data of T. Donnelly (personal communication).

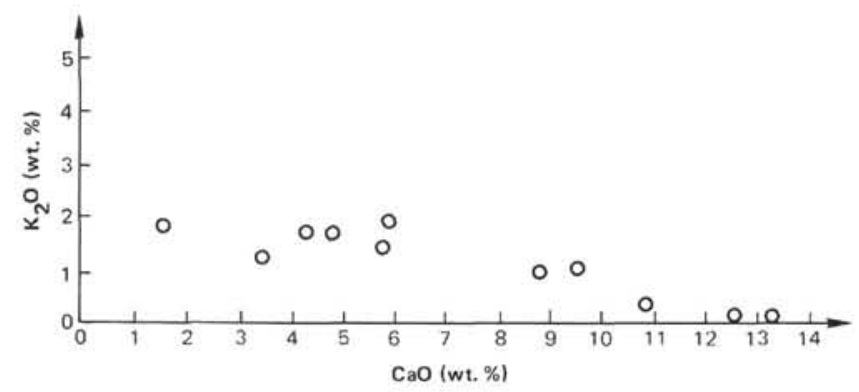

Figure 6. $\mathrm{CaO}-\mathrm{K}_{2} \mathrm{O}$ diagram for basalts from Hole $417 \mathrm{D}$.

cent $\mathrm{CaO}$, which implies that sodium is held in the rock up to a stage of intense alteration.

Other chemical constituents of the volcanic rocks do not exhibit any prominent variation with degree of alteration. The $\mathrm{MgO}$ content is nearly invariable, in some places slightly decreasing and in others somewhat increasing. This constituent is present in large amounts in metastomatically formed clay minerals. Some loss of $\mathrm{MgO}$ is noted in the places of intense oxidation, where magnesium was displaced from the octahedral positions in the structure of layered silicates by ferric iron, and potassium-rich ferruginous celadonites were formed.

The minor elements, titanium and manganese, are present in fairly constant amounts, irrespective of the degree of alteration. In the decomposition of magmatic minerals and glass, they are partially extracted but not transported far.

The rocks from Hole 417D have a more uniform chemical composition than those of Hole 417A, owing to a low degree of alteration. In Figure 9, peaks of a significant decrease in $\mathrm{CaO}$ are seen only at some narrow intervals corresponding to breccias or layers of devitrified glassy material. At all the other intervals, the $\mathrm{CaO}$ contents are within the limits that are typical of unaltered basalts. The degree of iron oxidation in the rocks from Hole 417D is lower than in

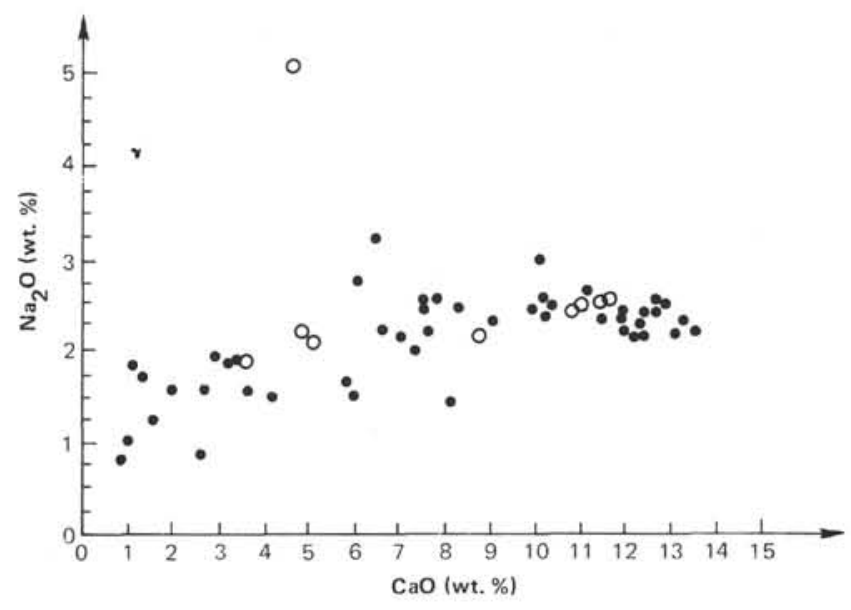

Figure 7. $\mathrm{CaO}-\mathrm{Na}_{2} \mathrm{O}$ diagram for basalts from Holes $417 \mathrm{~A}$ and $417 D$. For explanations, see Figure 5.

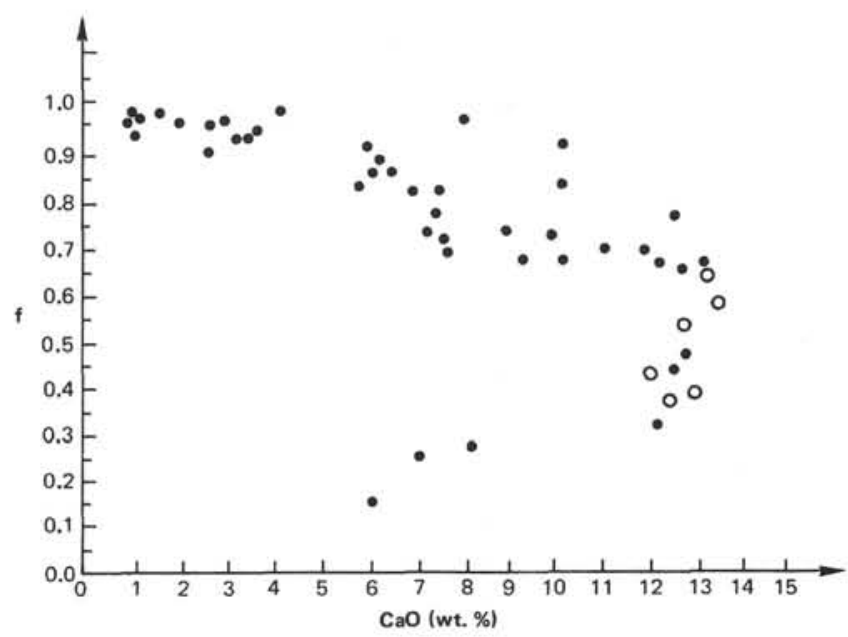

Figure 8. $\mathrm{CaO}-\triangle f$ diagram for basalts from Holes $417 \mathrm{~A}$ and 417D. Open circles $=$ unaltered rocks according to microscopic observations. $f=\mathrm{Fe}_{2} \mathrm{O}_{3} /\left(\mathrm{FeO}+\mathrm{Fe}_{2} \mathrm{O}_{3}\right)$.

those from Hole 417A, never approaching 1 . This is manifested by a greater development of magnesium montmorillonites and a lesser development of ferriceladonites, as compared to Hole $417 \mathrm{~A}$. The $\mathrm{K}_{2} \mathrm{O}$ contents, although exhibiting some similarity with the tendency noted in Hole 417A, display certain differences. For example, in the places of most altered rocks, the $\mathrm{K}_{2} \mathrm{O}$ content increases although not much (less than 3 per cent), whereas the rocks from Hole 417A yield $\mathrm{K}_{2} \mathrm{O}$ contents reaching 9 per cent. This difference is attributed to a small amount of K-feldspar in the cores from Hole $417 \mathrm{D}$, where the principal K-minerals are montmorillonites and mica-montmorillonites replacing both glass and plagioclase phenocrysts. Moreover, these minerals are low in potassium content. In general, the variation in chemical composition of the rocks from Hole 417D does not reveal a distinct decrease in the degree of alteration with depth; the alteration appears to be poor both at the top and at the bottom.

The degree of alteration in the cores is variable. Although a general tendency is toward decrease, there are considera- 


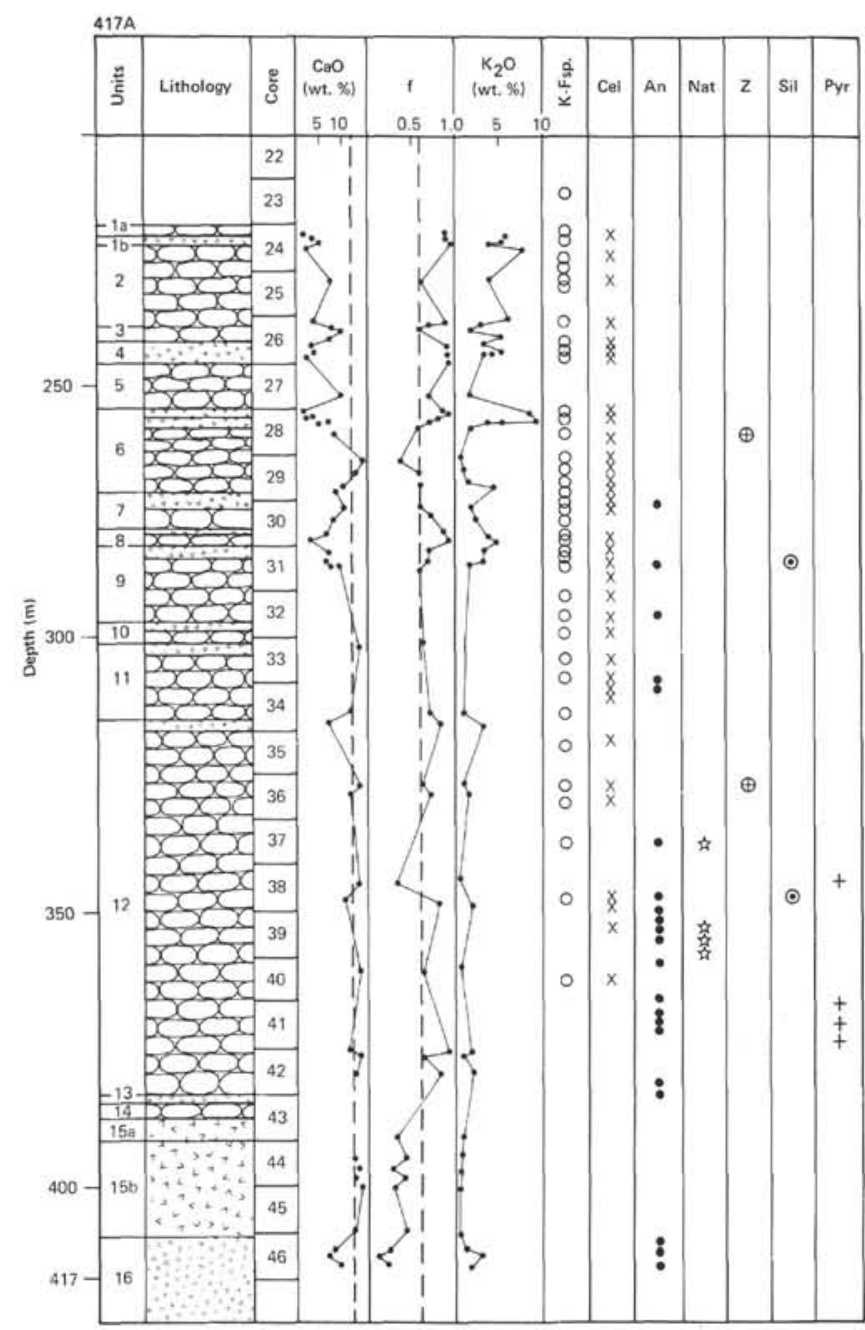

Figure 9. Distribution of some secondary minerals in the holes: (a) $417 \mathrm{~A}$, (b) $417 \mathrm{D}$, and (c) $418 \mathrm{~A} .1=$ pillow lava, 2 = breccia and hyaloclastite, $3=$ massive coarsegrained subophytic basalts; $f=\mathrm{Fe}_{2} \mathrm{O}_{3} /\left(\mathrm{Fe}_{2} \mathrm{O}_{3}+\mathrm{FeO}\right)$. $A n=$ analcime, $K$-Fsp $=K$-feldspar, Nat $=$ natrolite, $P h=$ phillipsite, $P y r=$ pyrite, $\mathrm{Cel}=$ celadonite, $\mathrm{Ox}=$ ferrix oxides, $Z=$ zeolites, circles = analcime, square = apophyllite, $Q=$ quartz (triangles), $O \mathrm{l}=$ fresh olivine, and Sil $=$ silica minerals.

$\begin{aligned} \text { 25 } & =\text { Pillow lavas } \\ 2 & =\text { Breccias } \\ 3 & =\text { Holocrystalline basalts }\end{aligned}$

ble departures related to lithologic inhomogeneities. Holocrystalline basalts are less altered than fine crystalline glassy varieties, and lavas are less altered than hyaloclastic rocks and volcanic breccias. Alteration is commonly more intense along fractures (Figure 10).

The greatest alteration is observed in breccia zones. There are at least two types of breccias: those formed at the chilled margins of pillow lavas, and cold breccias exhibiting no direct relations to chill zones. In the former, basalt and glass fragments are cemented with massive glass or finegrained glass globules. The massive glass is of low porosity and impermeable to solutions; therefore, it is often preserved unaltered. In the case of fine-grained cement, glass globules are completely replaced by smectite, the pseudomorph patterns being preserved.

In cold breccias, the cement is predominantly smectite, occasionally with some carbonate material. The smectite has no pseudomorph spheroidal structure, being rather of a vein type. Small basalt fragments are also replaced by smectite, larger fragments exceeding 2 to $5 \mathrm{~mm}$ being preserved. It is remarkable that sometimes different basalt fragments, even in the same thin section, have different vesicle fillings and pseudomorphs after olvine. In some fragments the filling consists of smectite, in others of carbonate or celadonite.

Evidently, the alteration of basalts was a long-term process. Even their brecciation and the formation of smectite cement appear to be a later process.

\section{DISTRIBUTION OF ALTERATION PRODUCTS IN DEPTH INTERVALS AND STRATIGRAPHIC LEVELS}

Figure 9 schematically shows the distribution of specific minerals resulting from basalt alteration as a function of depth and the adopted stratigraphic division of the basalt series.

The most prominent correlation is observed between the appearance of $\mathrm{K}$-feldspar in pseudomorphs after plagioclase and the oxidation of basalts; i.e., a pronounced increase of the ratio, $\mathrm{Fe}_{2} \mathrm{O}_{3} /\left(\mathrm{Fe}_{2} \mathrm{O}_{3}+\mathrm{FeO}\right)$. The iron hydroxides have changed the basalts to gray-brown in zones varying from several centimeters to several decimeters in thickness, along cracks and clay streaks or in zones of fracturing.

Examination of thin sections reveals that plagioclase $\mathrm{K}$-feldspathization occurs not only within the outlines of oxidized basalts but extends several centimeters beyond them. Both oxidation and $\mathrm{K}$-feldspathization take place only at the top of the basalt series. Celadonite also seems to exhibit some regularity in its development. Its abundance decreases with depth. The occurrences of analcime in Holes 417A and 418A are restricted to moderately altered basalts below the zones of $\mathrm{K}$-feldspathization and oxidation.

No other plausible regularities have been established in the development of the basalt alteration products. Yet, a comparison of the alteration processes in different holes reveals certain regular differences. For example, in Hole $417 \mathrm{D}$, there are practically no zeolites; quartz and chalcedony are rare; analcime and apophyllite are absent; and $\mathrm{K}$-feldspathization is rather slight, occurring only at the very top of the core. Breccia horizons are not accompanied by the appearance of zeolites or K-feldspathization. In Hole $418 \mathrm{~A}$, although the general pattern of development and amounts of smectite, celadonite and calcite are similar, rather intense zeolization is observed at brecciated chilled margins, and silicification is noted. It is remarkable that in Hole 418A quartz, analcime, apophyllite, and zeolites are frequently found even in intervals of very fresh basalts, as irregular patches (up to several centimeters in size) where the basalt is intensely altered. A thick brecciated horizon in this drill hole is highly oxidized and K-feldspathized. The 


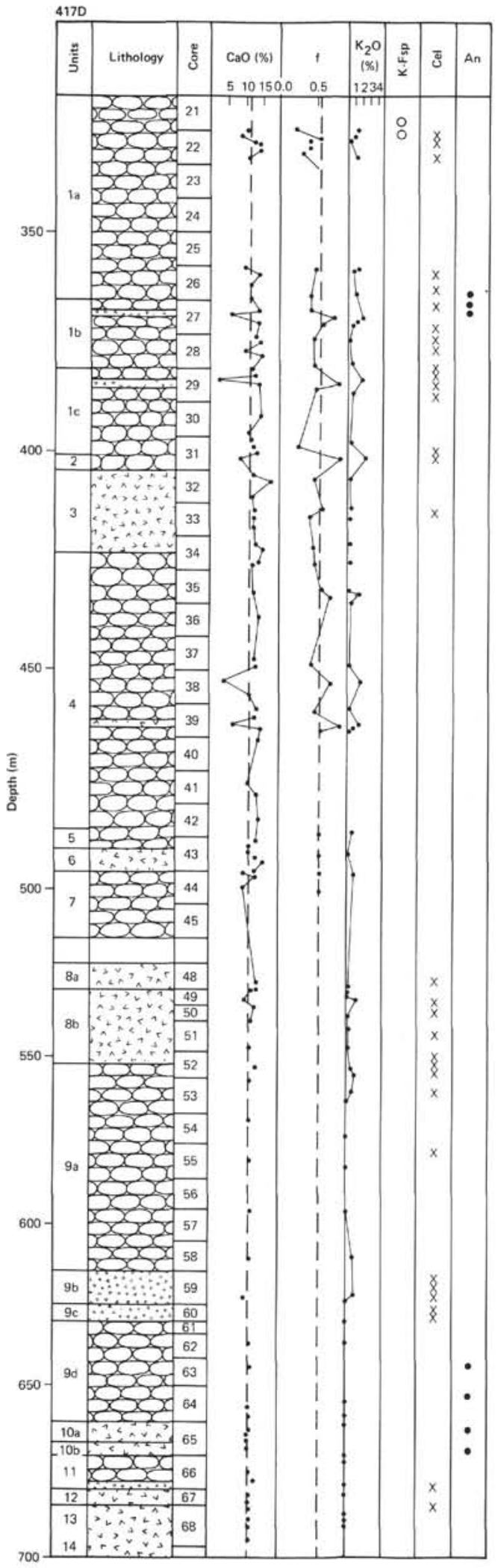

Figure 9. (Continued).

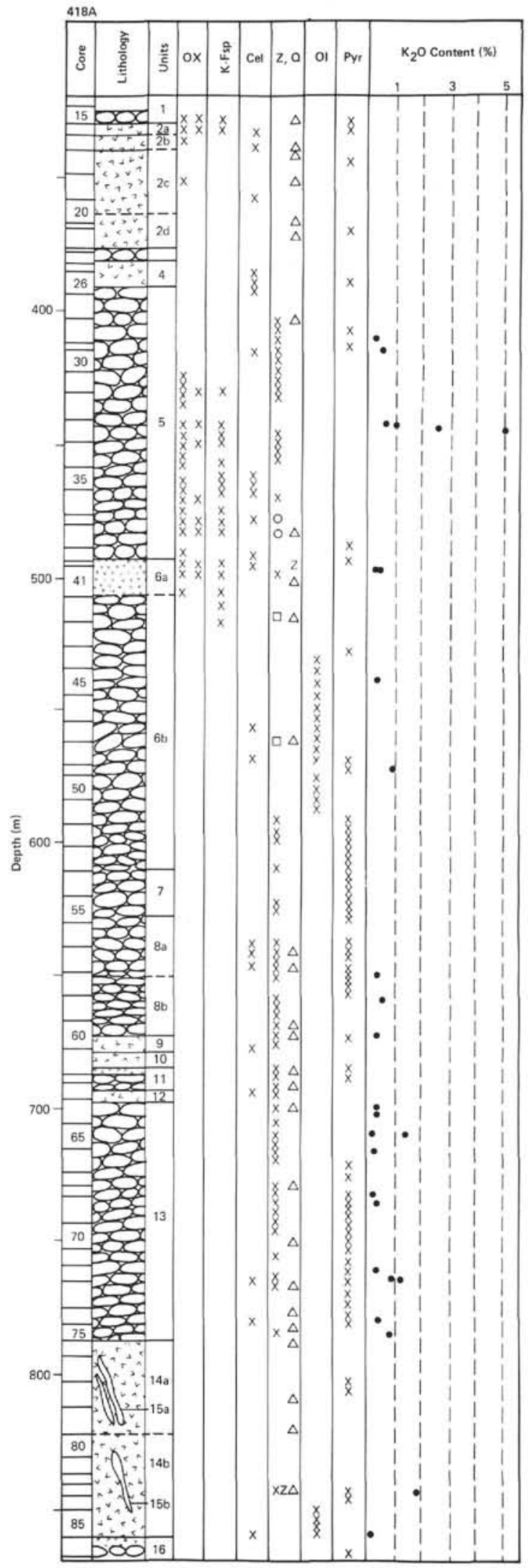




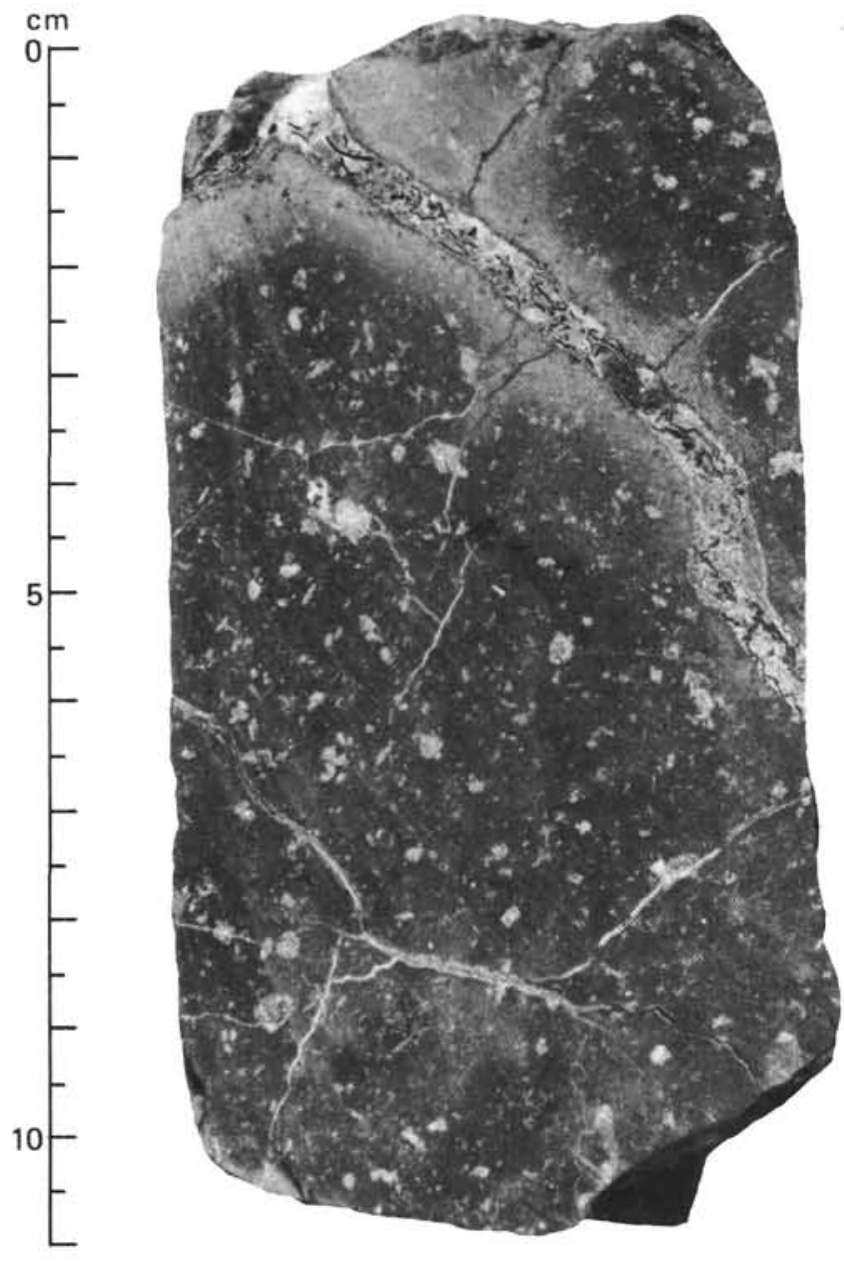

Figure 10. Basalt altered along a fissure, 417D-21, CC.

patches of intensely altered basalts in the fresh rock are likely to be tubular bodies of irregular shape formed along the routes of intensive circulation of solutions.

\section{SECONDARY ALTERATION ZONING}

The examination of thin sections has shown that the most representative alteration products exhibit a zonal pattern in their distribution. For example, the following zones were observed in a pillow lava near a chilled margin (Specimen $418 \mathrm{~A}-57-5,34 \mathrm{~cm}$ ): (1) a fine-grained groundmass with minute carbonate vesicles; (2) a somewhat coarser zone with olivine replaced by brown smectite, with some of the vesicles filled with the same brown smectite and others having only narrow rims of the smectite, the filling itself consisting of carbonate and the largest olivine phenocrysts being replaced by calcite and quartz; and (3) a still coarser zone where olivine and vesicles are replaced by bright green celadonite at the rims, which grades to light brown smectite in the cores.

The presence of the above-mentioned zones encouraged us to calculate the distribution of different replacement products as a function of distance from the chilled margin on the basis of the 400 samples available. This calculation has given some interesting results. Celadonite is formed most frequently near the chilled margin at a distance of several centimeters from it. Calcite developed in pseudo- morphs after olivine, in vesicle fillings, and in the groundmass occurs not far from the chilled margin $(25$ to $50 \mathrm{~cm})$. In massive basalt flows far from the chilled margin, such forms of calcite are present only near calcite veinlets and never far from them. An interesting case of a zonal pattern in the distribution of alteration products has been observed in Section 418A-60-4, where a vesicle-rich basalt layer exhibits a megazonal pattern of vesicle fillings. In the upper 20 to $80 \mathrm{~cm}$ of the layer, the vesicles are filled predominantly with calcite. Calcite is markedly altered to smectite at a boundary of $80 \mathrm{~cm}$ in Section 4 . There are two types of calcite-quartz veinlets accompanied by various near-vein alterations. The earlier quartz-calcite veinlets and spots have $1-\mathrm{cm}$ rims with smectite-filled vesicles and more abundant smectite in the groundmass (Figures 11 and 12). The contact of smectite in the vesicles is very distinct, occasionally crossing vesicles. Part of the vesicles are filled with calcite (with a small amount of quartz) and the other part with smectite. The later, commonly thinner, calcite veinlets are accompanied by the rims of a similar thickness around the vesicle fillings, the fillings themselves consisting of carbonate (with quartz) (Figure 13). Where these thin veinlets run across the rims of the earlier veinlets, they are accompanied by the carbonate fillings of the vesicles, though of a lesser thickness. Such relations indicate a possible metasomatic replacement of smectite by carbonate and vice versa, depending on the composition of the solutions moving along the fractures.

Smectites and celadonite evidently exhibit near-vein zoning. Close to veinlets of smectite brighter in color than the surrounding mass or near veinlets of bright green celadonite, the same smectite or celadonite can be seen in pseudomorphs after olivine and in vesicles (at a distance of not more than several millimeters from the veinlet).

Zoning is also observed in pseudomorphs after olivine in vesicles and veinlets.

The relationships between the fillings of pseudomorphs after olivine and those of vesicles are classified into several types. The most common type occurs when olivine is replaced by smectite and the vesicles are filled with the same smectite. In this case, in pseudomorphs after olivine, smectites are present in two different forms: as a network of microveinlets with smectite patches arranged approximately along the veinlets, and as a finer smectite in the remaining blocks. The smectite in small olivine grains of the groundmass is wholly fine granular. The vesicles display a different structural pattern: the rims are radiate-fibrous and the core is very fine grained. Apparently, at an early stage, the metasomatic replacement of olivine and deposition of smectite on the walls of vesicles from water solutions constituted a sufficiently slow process. Later, the process was accelerated, causing more rapid deposition of fine-grained material. The smectites of the pseudomorphs and vesicles are basically similar in composition, which is indicative of saturation of the solutions with smectite. Olivine is replaced by the smectite without adopting its composition.

The second type differs from the first in that the calcite fills the cores at least of the larger vesicles. Where calcite deposition took place, the solutions were saturated (but not oversaturated) with $\mathrm{CaCO}_{3}$; during the replacement of olivine, calcite was not yet deposited. 


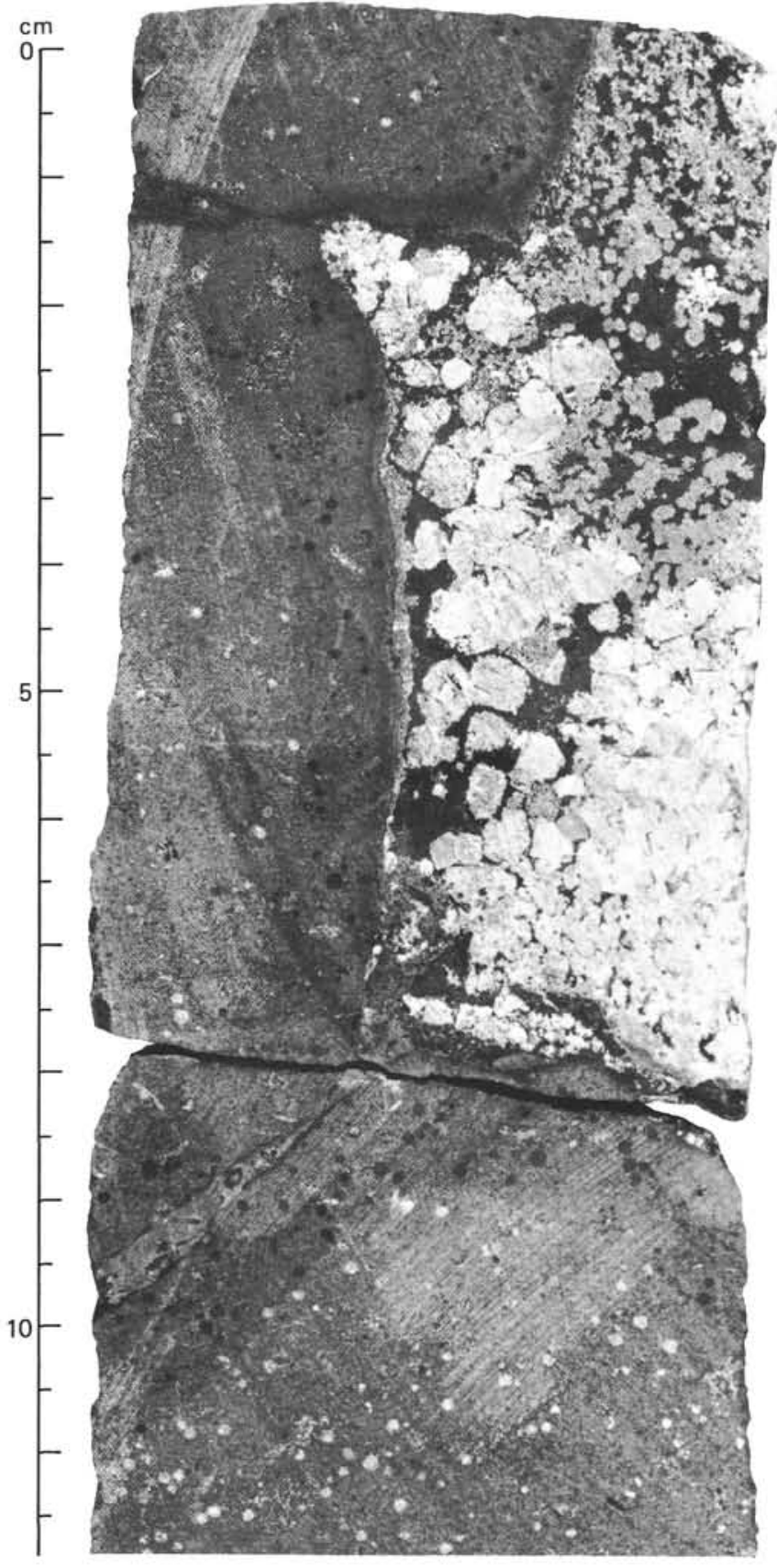

Figure 11. Angular space filled by calcite (large white crystals), quartz (small gray crystals) and smectite (dark gray) is rimmed by a band of vesicles with smectite fillings; 418A-60-4, 27-38.

The third type is distinguished by the presence of calcite in the pseudomorph cores or by the pseudomorphs wholly consisting of calcite. Apparently, in this case the solutions were considerably oversaturated with $\mathrm{CaCO}_{3}$, and the crystallization pressure of $\mathrm{CaCO}_{3}$ was higher than that of smectite.

Apart from the general case in which the clay mineral of the vesicle fillings shows no color zoning, there are very rare cases in which such zoning can be observed. Where celadonite is present in the filling it usually forms the rim, while the core is filled with yellow or light brown smectite.

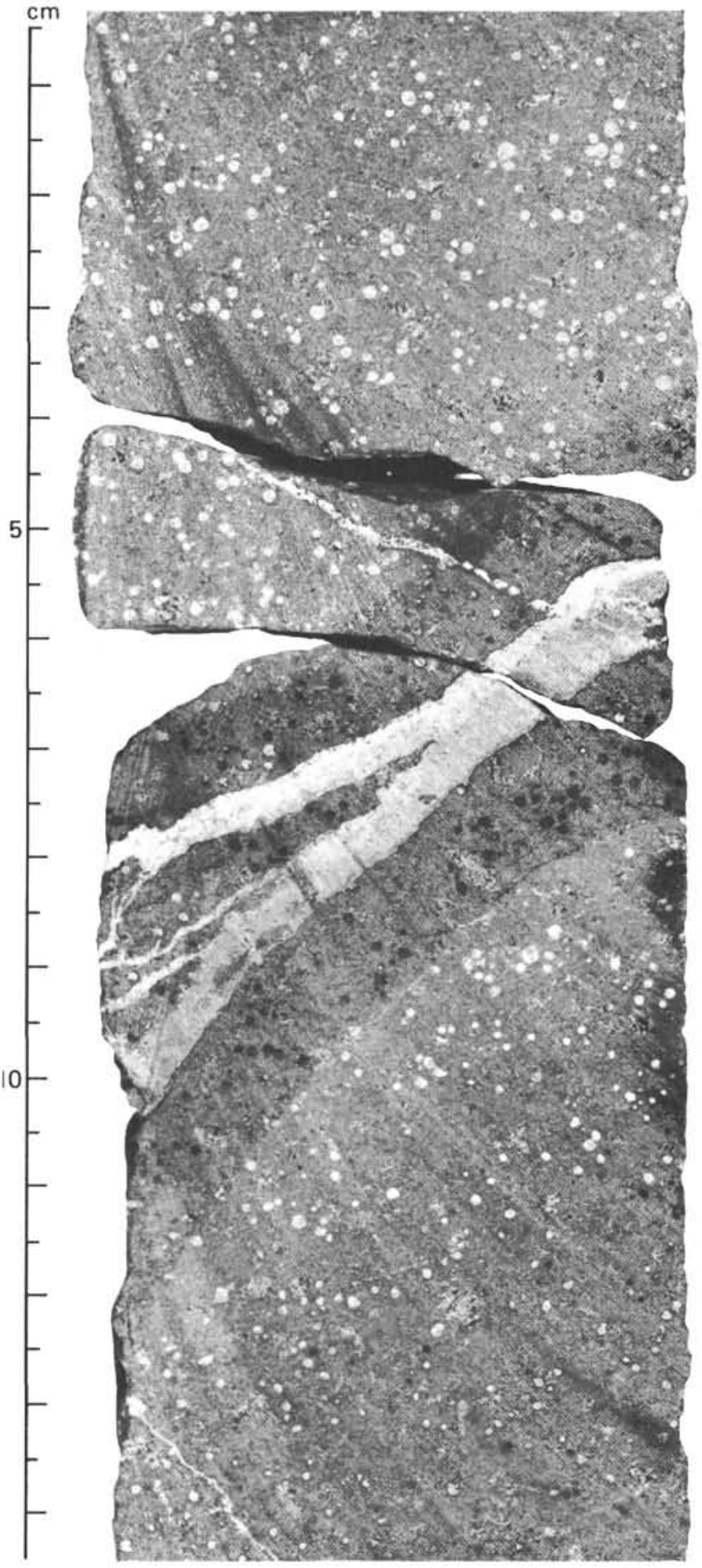

Figure 12. A quartz-calcite vein in basalt with calcite-filled vesicles; 418A-60-4, 45-60. Near the vein, vesicles are filled with smectite.

Among other instances of color zoning in smectites, light colored rims and somewhat darker cores are most common.

\section{SUCCESSION OF FORMATION AND PARAGENESES OF SECONDARY MINERALS}

No definite order could be established in the succession of the formation of secondary minerals; yet, some trends 


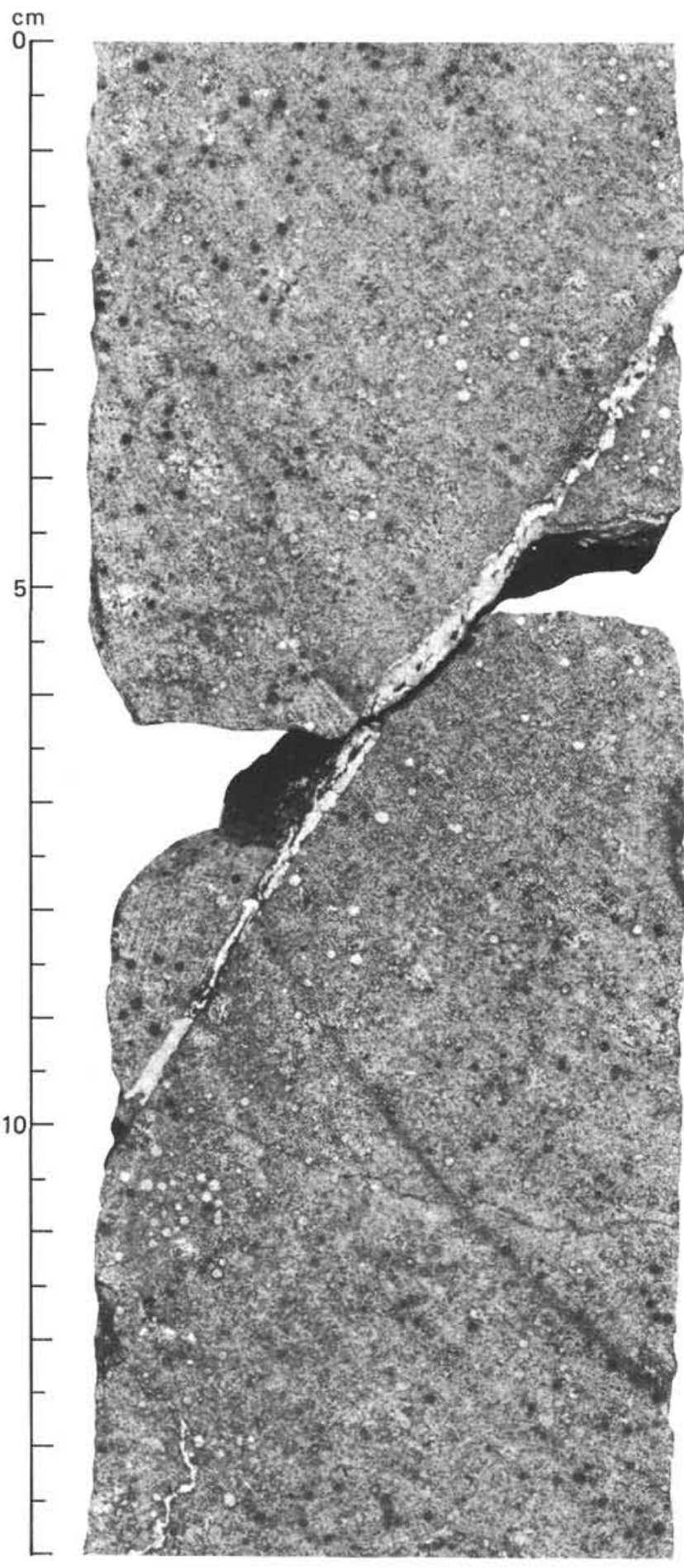

Figure 13. Carbonate vein in basalt with smectite vesicles; 418A-60-4, 104-120. Near the vein, vesicles are filled with calcite.

can be outlined. The assemblage of celadonite with smectite minerals is usually indicative of an earlier origin of celadonite. This is evidenced by celadonite being present more commonly in the rims than in the cores of vesicles. However, there are cases of metasomatic relationships where only one edge of a vesicle is filled with smectite, or where celadonite is present in the core. In other instances, veinlets of celadonite and cross-fibrous calcite cut across the smectite in the vesicles. In cold breccias, the earlier smectites and celadonite are cemented with smectite. Obviously, of all the secondary minerals smectites have the broadest range of origin.

The relations of celadonite and calcite are better established. The early cross-prismatic calcite is commonly contemporaneous with celadonite. For example, part of a thin veinlet can be composed of calcite and the other part of celadonite. Similar relationships can be observed between cross-prismatic calcite and smectite, although part of the latter was undoubtedly formed earlier than calcite. Celadonite or smectite occasionally occur in the fractures of calcite veins and were formed simultaneously with the calcite. But the later block calcite deposited during fissuring along the earlier veinlets cements the broken fragments of celadonite or smectite selvages and veins (Plate 5, Figure 1).

The position of zeolites, analcime, and apophyllite, in the succession of secondary minerals is uncertain. No correlation exists between the appearances of zeolites and the early celadonite. Quartz and chalcedony also seem to be rather late minerals; most commonly, they occur in the central part of large cavities filled with calcite or in the formations between pillows.

Secondary sulfides are closely associated with other secondary minerals, from early smectites and celadonites to calcite and quartz.

Oxides and $\mathrm{K}$-feldspar belong to the latest minerals. Their formation is accompanied by the oxidation of iron from smectites and celadonites. Yet, in large cavities. the appearance of oxides is fixed between the deposition of radiate-fibrous and block calcite (Plate 5, Figure 2).

Consequently, the succession of the secondary minerals can be represented only approximately, as shown in Figure 14.

\section{GENESIS OF SECONDARY ALTERATIONS IN BASALTS}

The absence of high-temperature alteration in basalts and the presence of low-temperature minerals indicate rapid so-

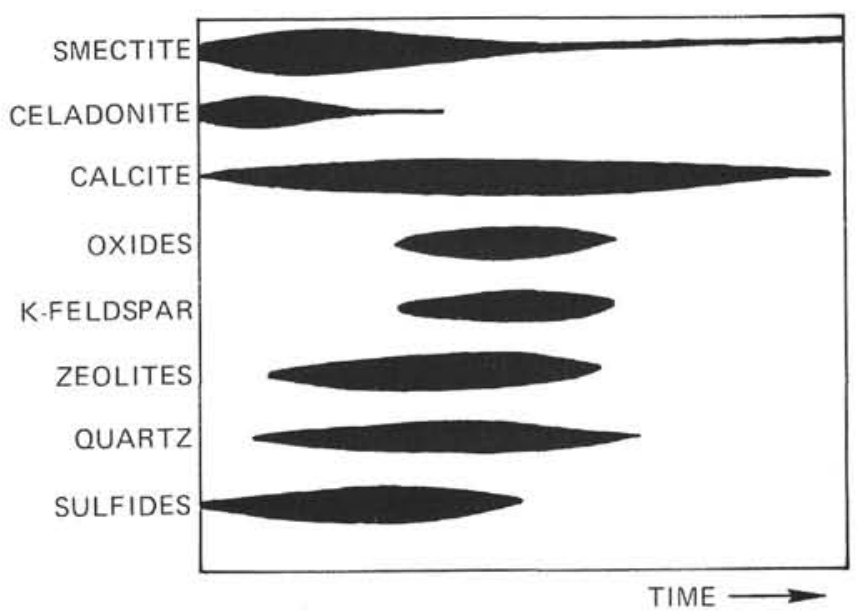

Figure 14. Schematic diagram of mineral formation during the alteration of basalt. 
lidification of the entire basalt series penetrated by drill holes of these legs, and the interaction between fresh cold basalts and low-temperature solutions. Generally, such activity is associated with halmyrolysis, i.e., with the alteration produced by the action of cold sea water (seawater weathering). Yet, the differences in the alteration of similar basalts from various closely spaced drill holes suggest other sources of solutions.

\section{Temperature}

From a study of the isotopic composition of oxygen of the calcites from the groundmass (Muehlenbachs and Scarfe, this volume), the temperature was found to be $37^{\circ}$ to $40^{\circ} \mathrm{C}$. Similar determinations on basalts from the Mid-Atlantic Ridge (Leg 37 ) yielded only $4^{\circ} \mathrm{C}$. Our study of the basalt alteration has shown that calcite in the groundmass is usually formed near calcite veinlets. Also, calcites in veinlets exhibit intricate structure-age relationships. It is not known to what age interval the calcites belong whose temperature of formation was determined to be $37^{\circ}$ to $40^{\circ} \mathrm{C}$. Nevertheless, at some intervals of the basalt alteration the temperature was rather high, and this suggests a high heat flow.

\section{Radiometric Age of Alteration Processes}

$\mathrm{K}$ - $\mathrm{Ar}$ age determination indicated that the most intensively altered basalts (including alteration by oxidation and $\mathrm{K}$-feldspathization) are 60 to $70 \mathrm{~m}$.y. old, although greater ages were determined in Hole 418A (112 and $87 \mathrm{~m} . \mathrm{y}$.). It is difficult to interpret these results. Most likely, the basalt alteration occurred at a period of intense tectonic activity, when the rocks were crushed and displaced producing new routes for solutions. Apparently, the most intense burst of tectonic activity occurred 60 to $70 \mathrm{~m}$.y. ago. The K-Ar age datings are discussed in a separate paper (Rusinov, Pertsev, et al., this volume).

\section{Formation of K-Feldspar, Analcime, Zeolites, and Oxides}

As mentioned above, these minerals in some places seem to be superimposed over the normal basalt alteration that produced celadonite, smectite, calcite, and pyrite. The appearance of zeolites is often restricted to probable solution channels which could be present even in poorly altered basalts. In Holes $417 \mathrm{~A}$ and $418 \mathrm{~A}, \mathrm{~K}$-feldspar occurs in breccia zones and in zones of intense fracturing, whereas in Hole 417D neither oxidation nor K-feldspathization is found even in the upper breccia zones. This indicates the rise of warm solutions rich in $\mathrm{K}_{2} \mathrm{O}$.

Finally, the appearance of apophyllite in relatively poorly altered basalts also favors the proposition of acting hydrothermal solutions carrying fluorine of non-marine origin.

In conclusion, the evidence suggests that abyssal hydrothermal solutions (though low temperature) participated in alteration processes of the basalts drilled on these legs. This hydrothermal activity followed the halmyrolysis process and occurred at periods of intense tectonic activity.

\section{REFERENCES}

Deer, W. A., Howie, R. A., and Zussman, J., 1962. Rockforming minerals: London (Longmans, Green), v. 3.

Hart, R. A., 1973. A model for chemical exchange in the basaltseawater system of oceanic Layer 2, Canadian J. Earth Sci., v. 10 , p. $799-816$.

Robinson, P. T., Flower, M. F. J., Schminke, H. U., and Ohnmacht, W., 1977. Low temperature alteration of oceanic basalts, DSDP, Leg 37. In Aumento, F., Melson, W. G., et al., Initial Reports of the Deep Sea Drilling Project, v. 37: Washington (U.S. Government Printing Office), p. 775-794.

Scott, R. B. and Hayash, A., Jr., 1976. Initial submarine alteration of basaltic pillow lavas: a microscopic study, Am. J. Sci., v. 276 , p. $480-501$. 



\section{PLATE 1}

Figure 1 Amygdule in basalt filled with smectite, celadonite, and black layers of hydroxides of iron and manganese. Without analyzer. Specimen 418A-60-4, 49 $\mathrm{cm}$.

Figure 2 Vesicle in basalt filled with calcite (center), finegrained smectite (dark), and with a rim of spherulitic smectite (light). Crossed nicols. Sample 417D-65-4, $31-33 \mathrm{~cm}$.

Figure 3 Spherulitic quartz in a calcite vein. Crossed nicols.

Figure 4 Vesicle in basalt filled with quartz, calcite, and smectite. Crossed nicols. Specimen 418A-60-4, $34 \mathrm{~cm}$. 

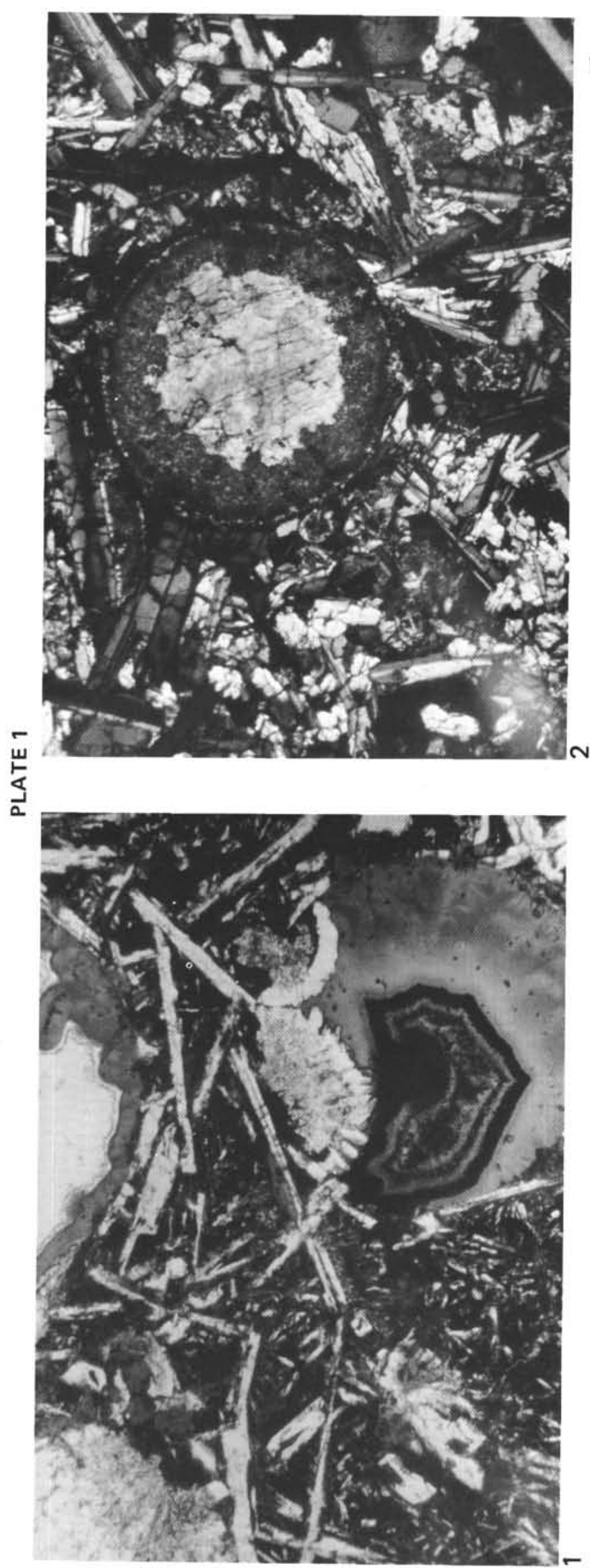

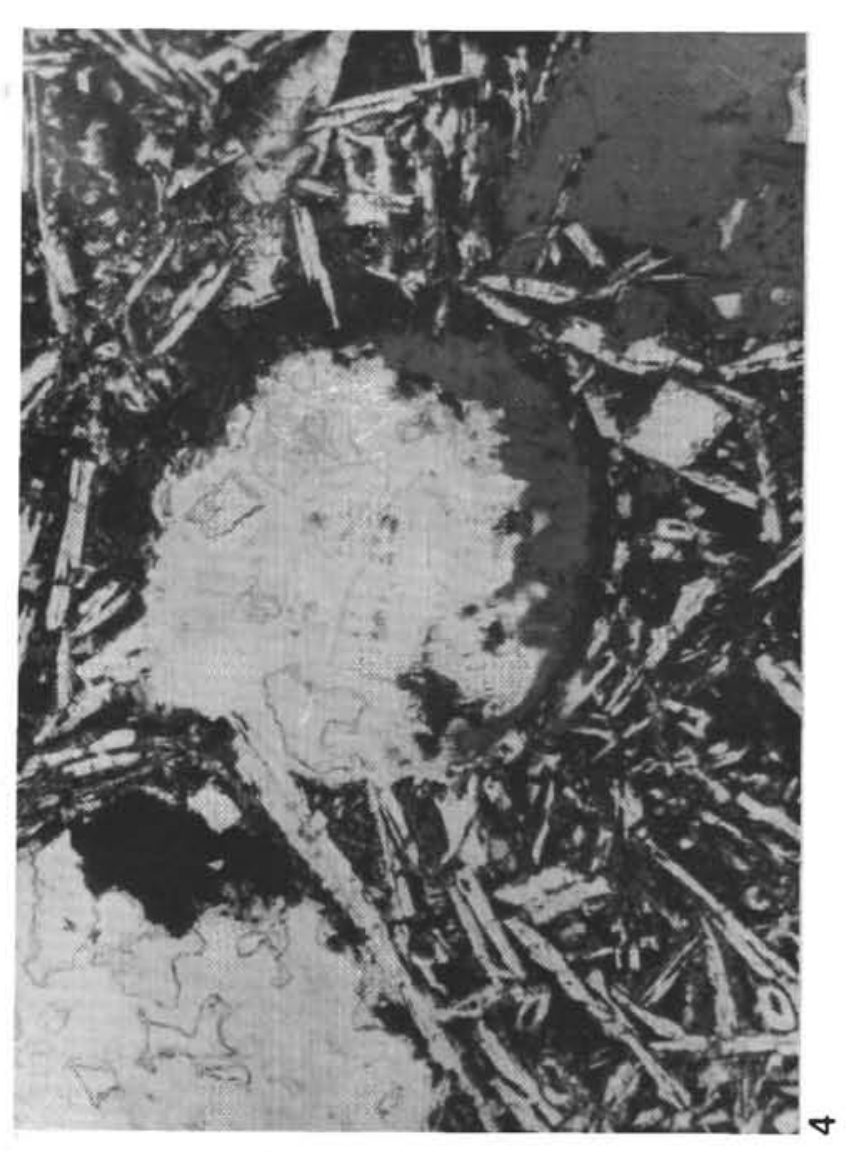

86,12

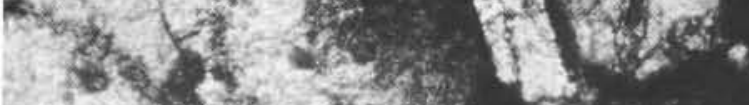
2. M X

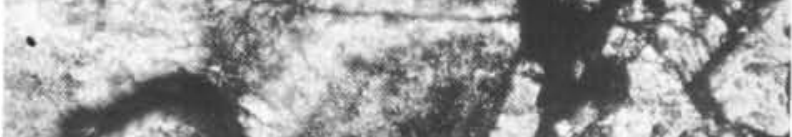
2.t.

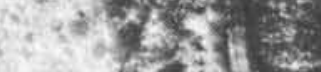

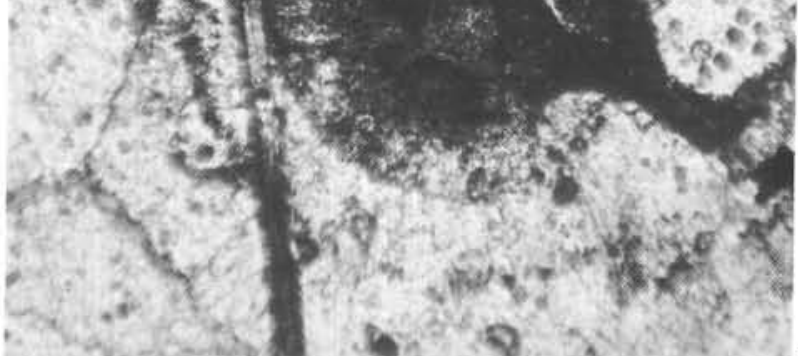




\section{PLATE 2}

Figure $1 \quad$ Quartz and smectite replacing an olivine phenocryst. Crossed nicols. Sample 417A-43-1, 59-62 cm.

Figure 2

Vesicle in basalt filled with calcite, surrounded with a rim of opal. Crossed nicols. Sample 418A-22-1, $12-15 \mathrm{~cm}$.

Figure 3 K-feldspar replacing plagioclase phenocryst. More sodic plagioclase is preserved in the rims. Crossed nicols. Specimen 417D-21-4, $57 \mathrm{~cm}$.

Figure 4 Altered basalt with lamellae of apophyllite and with smectite. Specimen $418-48-1,85 \mathrm{~cm}$. 

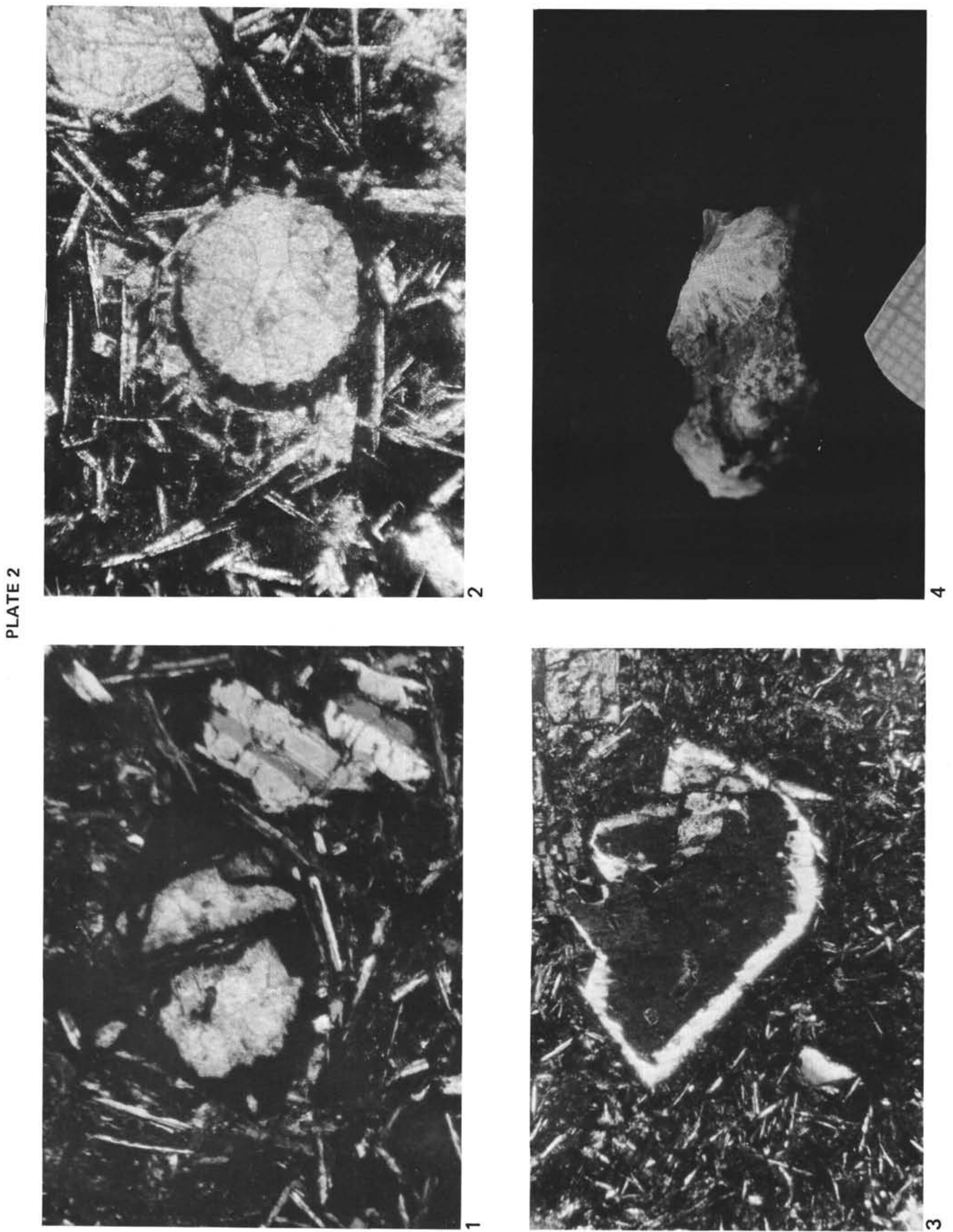


\section{PLATE 3}

Figure $1 \quad$ Rhombohedral crystals of calcite (white) in analcime (dark). Crossed nicols. Specimen 418A-38-1, $3 \mathrm{~cm}$.

Figure 2

Fibrous phillipsite (white) and analcime (dark) replacing plagioclase phenocrysts in basalt. Crossed nicols. Sample 418A-40-2, $43-48 \mathrm{~cm}$.

Figure 3

Pyrite grains enclosed in a smectite vein and emplaced along vein boundaries. Reflected light. Specimen $418 \mathrm{~A}-67-1,123 \mathrm{~cm}$.

Figure $4 \quad$ Pyrite in a vein of normal-fibrous calcite and in a smectite vesicle. Reflected light. Specimen 418A$69-1,48 \mathrm{~cm}$. 

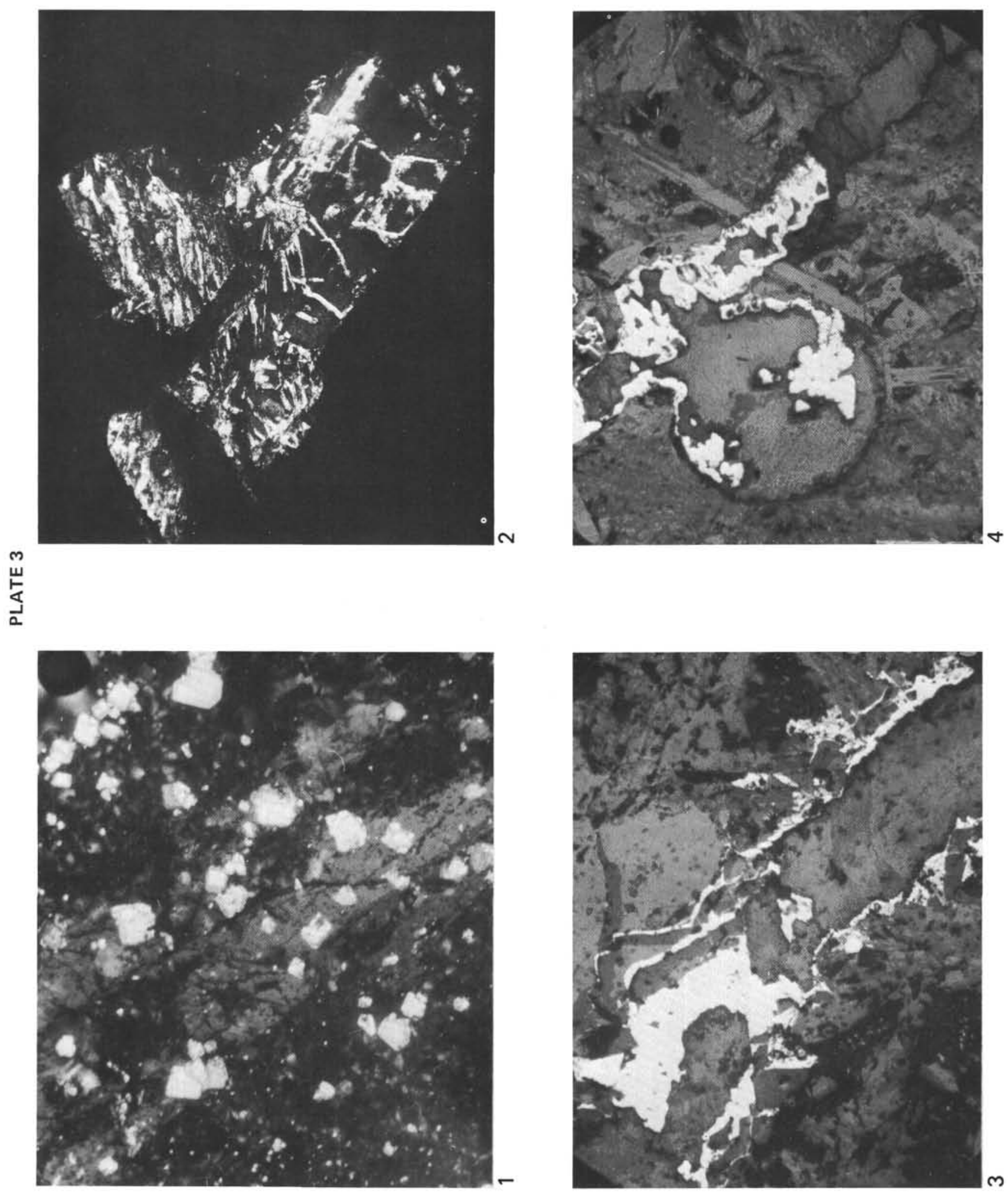


\section{PLATE 4}

Figure 1 Pyrite crystals in basalt rimmed by a mixture of pyrite and smectite. Reflected light. Specimen 418A-79-2, $48 \mathrm{~cm}$.

Figure 2 Magnetite crystals are replaced partly by pyrite and fine mixture of sulfides and smectite. Reflected light. Specimen 418A-79-2, $48 \mathrm{~cm}$.

Figure $3 \quad$ Vesicle filled with smectite and rimmed with pyrite. Reflected light. Specimen 418A-57-2, $73 \mathrm{~cm}$. 


\section{PLATE 4}

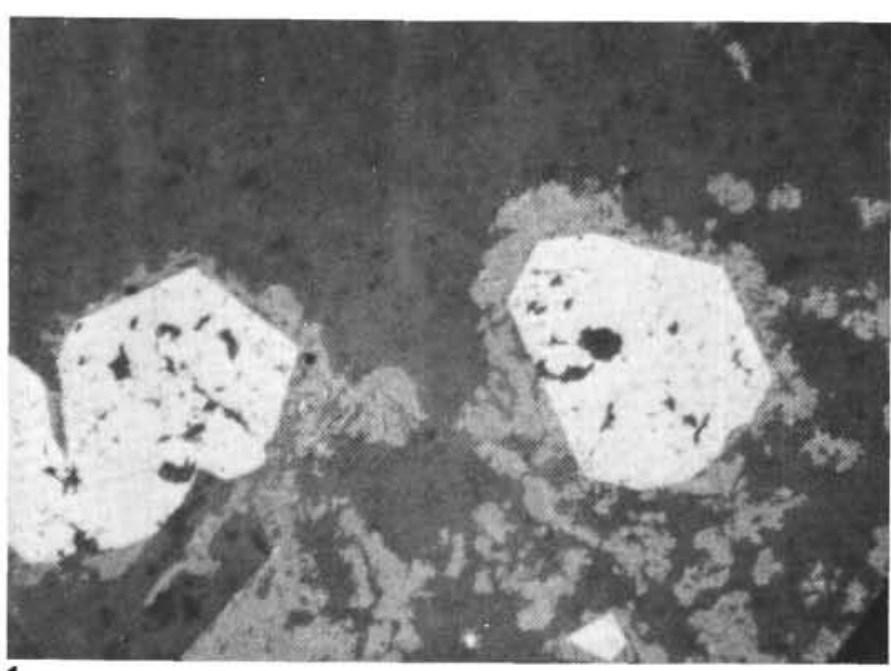

1
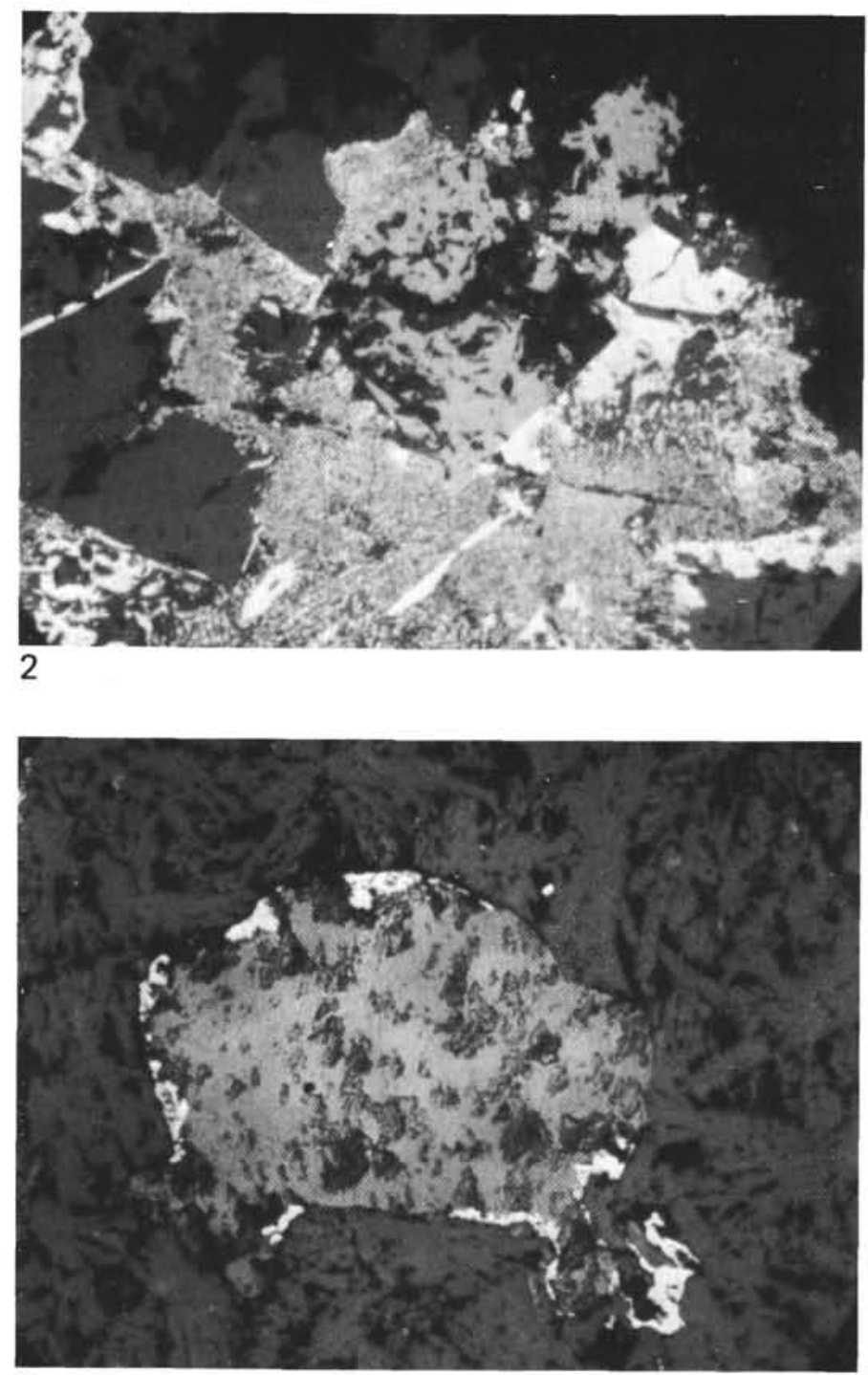

3 


\section{PLATE 5}

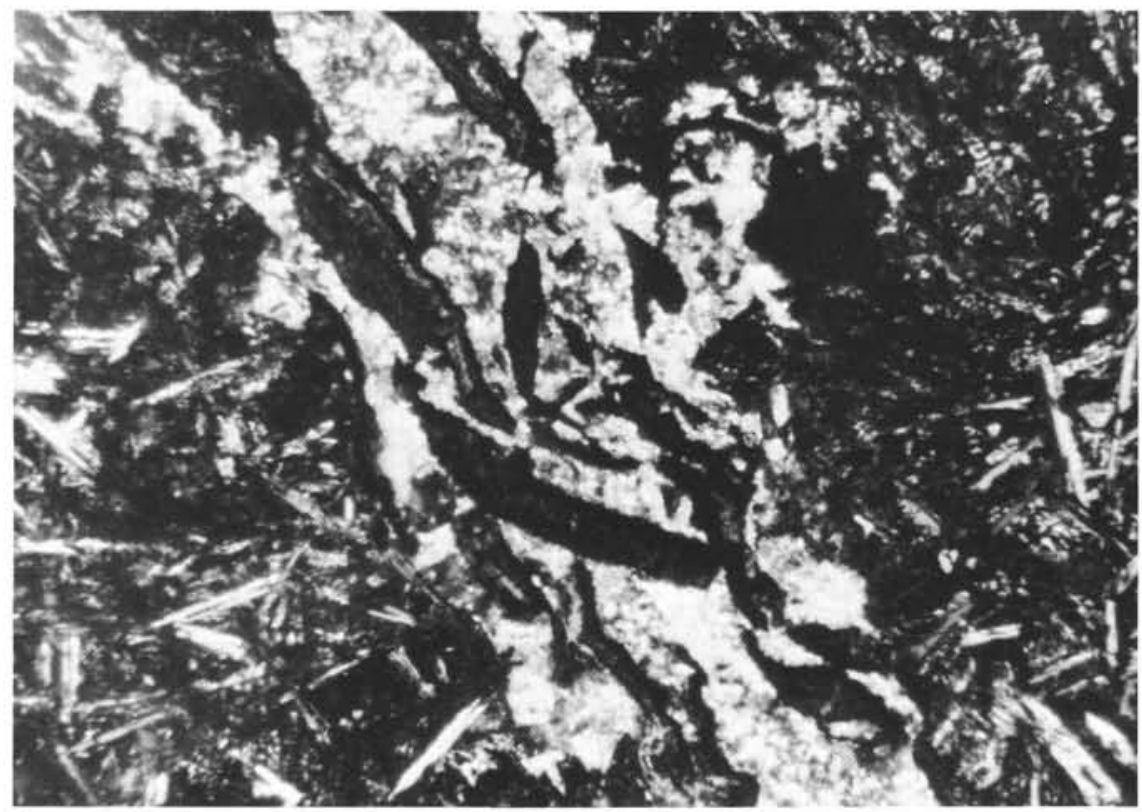

1

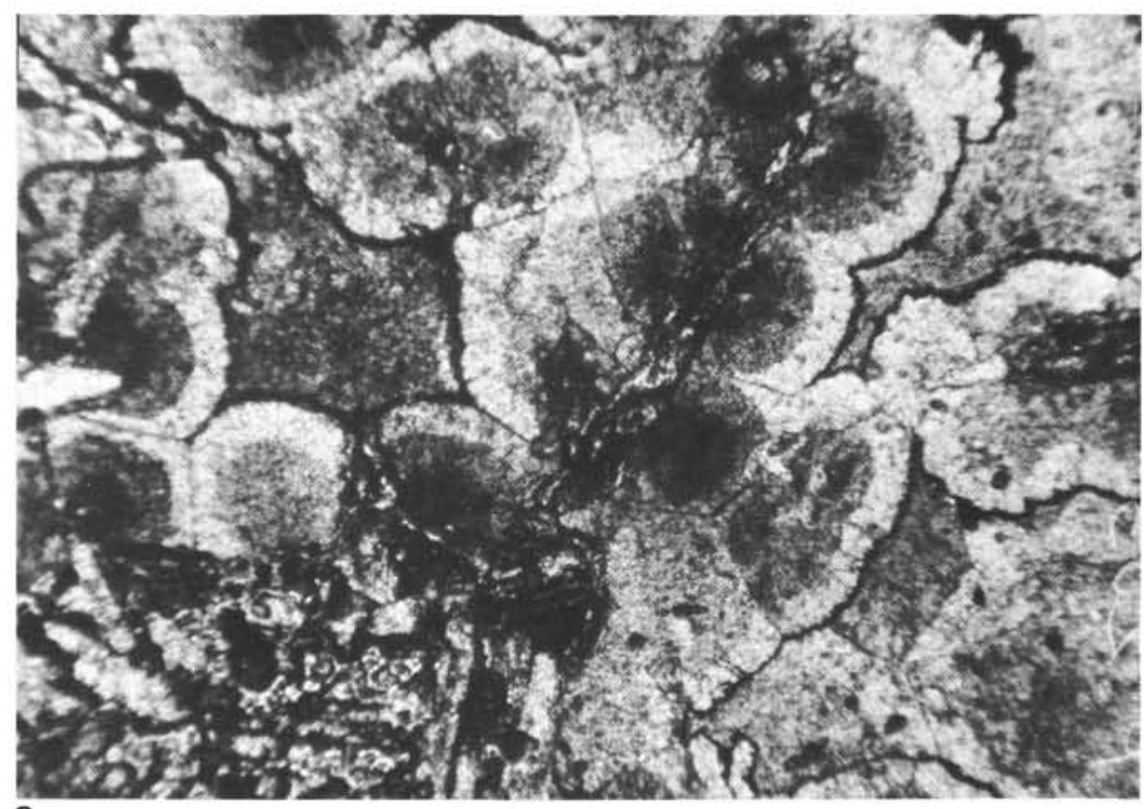

2

Figure 1

Veinlet of calcite containing fragments of celadonized glass. Without analyzer.

Figure 2 Vesicle with zonal distribution of coarse-grained and spherulitic calcite. Between the two types of calcite are some Fe hydroxides (black). Without analyzer. Sample 418A-19-7, 109-111 cm. 